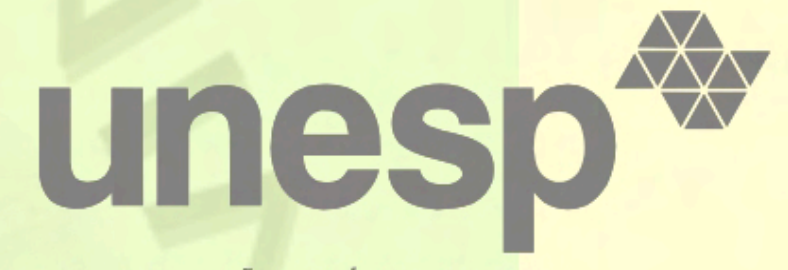

CAMPUS DE SÃO JOSÉ DO RIO PRETO

\title{
Uso de Recursos e Padrão de Co-ocorrência com Insetos Predadores em Comunidades Sub-tropicais de Girinos
}

\section{Diogo Borges Provete}

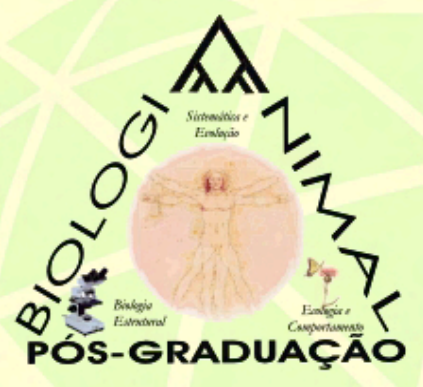

$$
\begin{aligned}
& \text { PÓS GRADUAÇÃO } \\
& \text { EM BIOLOGIA ANIMAL }
\end{aligned}
$$




\author{
UNIVERSIDADE ESTADUAL PAULISTA \\ INSTITUTO DE BIOCIÊNCIAS, LETRAS E CIÊNCIAS EXATAS \\ SÃo JosÉ DO RIO PRETO - SP
}

Programa de Pós-Graduação em Biologia Animal

\author{
Diogo Borges Provete \\ Biólogo
}

\title{
Uso de Recursos e Padrão de Co-ocorrência com Insetos Predadores em Comunidades Sub- Tropicais de Girinos
}

\author{
Orientador: Prof. Dr. Itamar Alves Martins \\ Co-ocientadora: Profa. Dra. Denise de Cerqueira Rossa Feres
}

Dissertação apresentada para obtenção do título de Mestre em Biologia Animal, junto ao Programa de PósGraduação em Biologia Animal do Instituto de Biociências, Letras e Ciências Exatas da Universidade Estadual Paulista "Júlio de Mesquita Filho", campus de São José do Rio Preto.

São José do Rio Preto-SP 
Provete, Diogo Borges.

Uso de recursos e padrão de co-ocorrência com insetos predadores em comunidades sub-tropicais de girinos / Diogo Borges Provete. - São José do Rio Preto : [s.n.], 2010.

88+vii f. : il. ; $30 \mathrm{~cm}$.

Orientador: Itamar Alves Martins

Co-orientadora: Denise de Cerqueira Rossa-Feres

Dissertação (mestrado) - Universidade Estadual Paulista, Instituto de Biociências, Letras e Ciências Exatas

1. Ecologia de comunidades. 2. Anfíbio. 3. Girino-Diversidade. 4. Girino-Dieta. 5. Partilha de recursos. 6. Seleção de hábitat. I. Martins, Itamar Alves. II. Rossa-Feres, Denise de Cerqueira. III. Universidade Estadual Paulista, Instituto de Biociências, Letras e Ciências Exatas. IV. Título.

CDU - 574

Ficha catalográfica elaborada pela Biblioteca do IBILCE

Campus de São José do Rio Preto - UNESP 
Banca examinadora:

Titulares:

Prof. Dr. Itamar Alves Martins:

UNITAU-Orientador

Prof. Dr. Luis Cesar Schiesari:

\section{EACH-USP}

Profa. Dra. Lilian Casatti:

\section{IBILCE-UNESP}

Suplentes:

Dra. Maria Stella Maioli Castilho Noll:

IBILCE-UNESP

Profa. Dra. Cynthia Peralta de Almeida Prado:

UNESP-Jaboticabal 
"O caminho mais agradável e pacífico na vida é o que segue pelas avenidas da ciência e da instrução, e todo aquele que for capaz de remover algum obstáculo nesse caminho, ou descortinar novas perspectivas, deve, nessa medida, ser considerado um benfeitor da humanidade. E embora essas pesquisas possam parecer penosas e fatigantes, ocorre com algumas mentes o mesmo que com alguns corpos, os quais, tendo sido dotados de uma saúde vigorosa e exuberante, requerem severo exercício e colhem prazer daquilo que parece árduo e laborioso à humanidade em geral. A escuridão, de fato,

é tão dolorosa para a mente como para a vista, mas obter luz da escuridão por mais esforço que acarrete, será sem dúvida motivo de júbilo e deleite (...), o raciocínio justo e exato é o único remédio universal".

David Hume (1748), Uma investigação sobre o entendimento humano

À minha Família, por me permitir ter sonhos e participar das suas realizações.

Dedico também esta dissertação à memória de Fernando Martins Couto (1977-2009), amigo de todas as horas que perdemos para a violência urbana. 


\section{AGRADECIMENTOS}

Este período que passei em Rio Preto foi repleto de vivências inigualáveis e também um período de intensa aprendizagem, que se refletiram tanto no aspecto profissional quanto no pessoal e por isso gostaria de agradecer imensamente a todas as pessoas que tornaram estes últimos três anos da minha vida inesquecíveis, são elas:

- Profa. Dra. Denise de Cerqueira Rossa Feres que me acolheu no seu laboratório, ainda como técnico da coleção e que acreditou em mim e me deu a oportunidade de trabalhar em conjunto com ela ao longo de todo esse tempo, dividindo comigo uma parcela da sua extensa experiência tanto como professora quanto pesquisadora, o seu exemplo de dedicação, ética profissional e paixão pelo que faz irá me acompanhar para sempre ao longo da minha carreira;

- Prof. Dr. Itamar Alves Martins, que aceitou a empreitada de me orientar durante o mestrado e mesmo à distância sempre demonstrou interesse e preocupação pelo que estava acontecendo aqui em Rio Preto, também pelas horas de descontração que tivemos em campo e na disciplina;

- Meus pais Dante Provete Neto, Habigail Borges da Silva Provete e minha irmã Francine Borges Provete que sempre apoiaram os meus planos de vida, e que apesar de nunca compreenderem direito porque eu gostava tanto de "sapos" e porque tinha de passar tanto tempo longe de casa, nunca se fartaram de me incentivar e consolar nas horas difíceis (que não foram poucas!);

- Profs. Drs. Luis Cesar Schiesari e Lilian Casatti que, como membros da banca de qualificação, contribuíram de forma decisiva para aumentar a qualidade deste presente estudo;

- Profs. que ministraram disciplinas das quais participei: Lilian Casatti, Francisco Langeani Neto, James Ha, Paulo E. Cardoso, Paulo R. Guimarães Jr., Gustavo Q. Romero, Itamar A. Martins, Paulo de Marco Jr., Vera C. Silva e Rui Rebelo, obrigado por todos os ensinamentos que me transmitiram;

- Prof. Dr. Gustavo Q. Romero que serviu para mim como um exemplo de profissional, e exerceu forte influência sobre o meu conceito do que é e de como fazer ciência de alta qualidade! Talvez você nem saiba o quanto me ensinou.

- Os profs. e coordenadores do curso de campo em Ecologia da Floresta Amazônica (INPA-PDBFF) que muito contribuíram para o meu crescimento profissional e 
pessoal ao me transmitir algo que não há como quantificar, tão pouco descrever com palavras: experiência de vida! Inesquecível, intensa e gratificante!

- Todos os membros atuais ou antigos do Laboratório de Ecologia Animal que tornaram o ambiente de trabalho agradável e me ajudaram de uma forma ou de outra a trilhar este árduo e prazeroso caminho da pós-graduação: Heloísa Jesus de Almeida, Thiago A. L. de Oliveira, Michel V. Garey, Vitor H. M. Prado (valeu pela ajuda com a CCA), Fernando R. Silva, Ricardo A. Brassaloti, Lucas Crivellari, Verônica T. T. de Sousa, Denise D. Dias, Rinneu E. Borges, Tiago S. Vasconcelos, Natacha Y. N. Dias, Fausto Nomura, Carlos E. Conte, Luciana Ortega, Tiago Motta, Felipe B. R. Gomes e o técnico Carlos Eduardo Souza.

- Amigos de república que dividiram comigo as alegrias e penúrias do mestrado: José Cesar Souza, Michel V. Garey e Thiago Gonçalves Souza.

- Muitos profissionais de uma maneira ou de outra me ajudaram à distância tentando sanar algumas dúvidas que me corroíam, gostaria de deixar aqui o meu sincero agradecimento e reconhecimento: Prof. Dr. Mario de Almeida Neto, Prof. Dr. Nicholas J. Gotelli, Prof. Dr. Werner Ulrich, Ms. Paula Hanna Valdujo, Ms. Allison M. Gainsburry, Prof. Dr. Ricardo J. Sawaya, Ms. Camila Both, Dr. Tiago Gomes dos Santos, Dr. William Ronald Heyer, Dr. Ermias T. Azeria, Dra. Shannon J. McCauley ;

- "and the last, but not least" a Lilian Franco Belussi que me ensinou a amar! E que tem tornado esses últimos meses, antes imersos no caos e desordem em algo maravilhoso, inefável e pleno de significado. Obrigado por você existir e fazer parte da minha vida!! ["how wonderfull life is,/now you're in the world"]

E como um trabalho desta magnitude não é de maneira alguma fruto de esforço individual, gostaria de agradecer àquelas pessoas que me ajudaram a torná-lo realidade e adquirir o formato atual:

- Gostaria de fazer ainda um agradecimento especial ao Ms. Michel Varajão Garey, acredito que se não fosse por ele este momento nunca poderia se realizar, o Michel foi alguém que acreditou em mim quando nem mesmo eu acreditava, me levantou e ao me convidar para enfrentarmos juntos o desafio de coletar na Bocaina me ajudou a concretizar o sonho de ser um aluno de pós-graduação e ser um ecólogo de campo. Além de me ajudar durante toda a minha trajetória na pós e transformar as noites gélidas e os dias entediantes na Bocaina em algo suportável e aprazível. Muito 
obrigado por tudo e tenho certeza de que você tem um grande e promissor futuro pela frente!

- Outro agradecimento especial que gostaria de deixar registrado é ao Ms. Thiago Gonçalves Souza, colega de república, companheiro de bar e um cara que me ensinou que é possível levar a vida mais leve e mesmo assim ser alguém que faz a diferença. Pode ter certeza de que você me influenciou pra caramba! Obrigado pelas conversas aleatórias sobre temas estocásticos ou determinísticos! Depois a gente faz um bootstrap e vê no que dá!!

- A graduanda Denise Deo Dias que aceitou o desafio de me auxiliar com a identificação do conteúdo da dieta dos girinos, sem o seu apoio e dedicação este trabalho nunca poderia ter se completado;

- Todos os funcionários do Parque Nacional da Serra da Bocaina e do PREVFOGO por todo o auxílio logístico e pelo fornecimento dos dados de temperatura, sem os quais este trabalho não seria de forma alguma exeqüível, também pela convivência sempre enriquecedora;

- Ao Prof. Dr. Jorge Luis Nessimian (IB-UFRJ) e seus alunos, bem como à Ms. Fernanda A. C. Silva (MN-RJ), Dra. Gisele Almeida (MN-RJ), Ms. Danielle A. dos Santos (MN-RJ) pelo auxílio na identificação dos insetos;

- O IBAMA-ICMBio pelo fornecimento das licenças de coleta (Proc. nº 14474 e 17331) sem as quais este estudo não seria possível;

- Os funcionários do departamento de Zoologia e Botânica e da seção de pósgraduação por todo o auxílio com as burocracias chatas;

- Os funcionários do DAE de Taubaté por fornecerem os dados pluviométricos da estação de Bananal;

- Pelo auxílio financeiro que possibilitou a minha manutenção aqui em São José do Rio Preto, as bolsas da CAPES-Demanda Social e da FAPESP (Proc. nº. 2008/557446) são imensamente reconhecidas. 


\section{ÍNDICE}

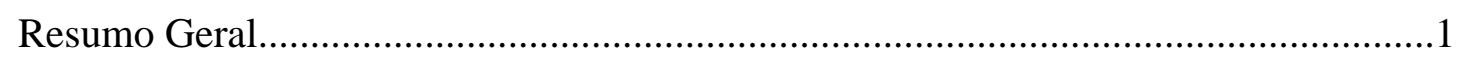

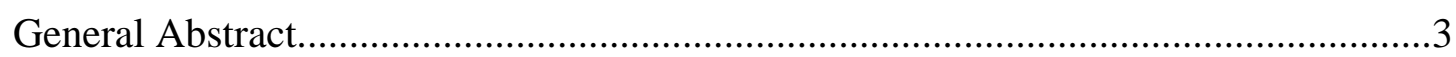

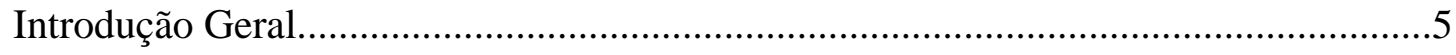

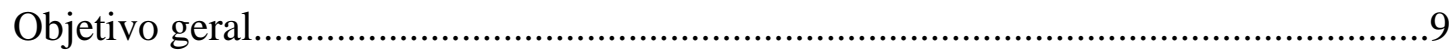

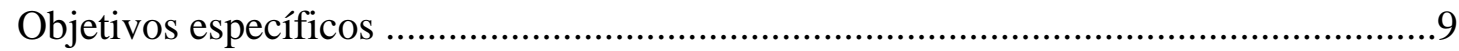

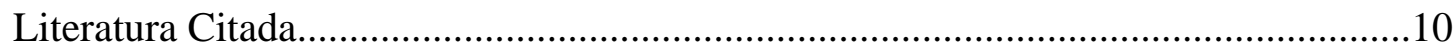

1. Capítulo 1: The role of abiotic factors in structuring assemblages of pond-dwelling tadpoles in the Brazilian Atlantic Rain Forest..........................................................13

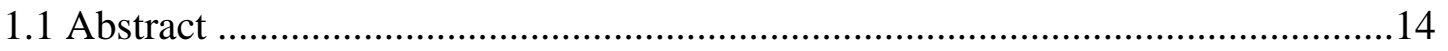

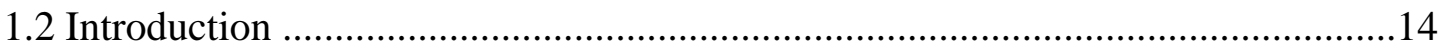

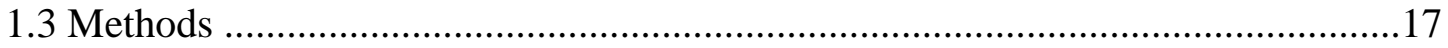

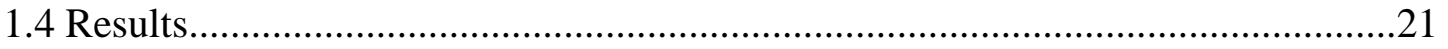

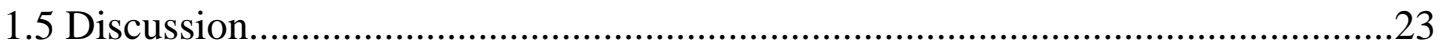

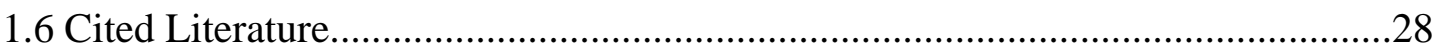

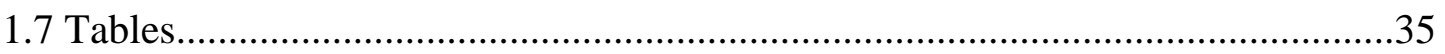

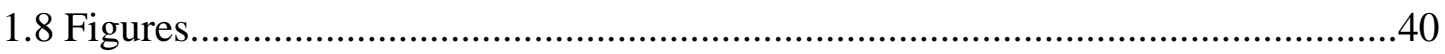

2. Capítulo 2: Niche partitioning in an assemblage of pond-dwelling

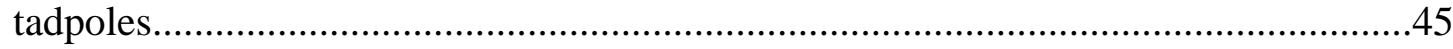

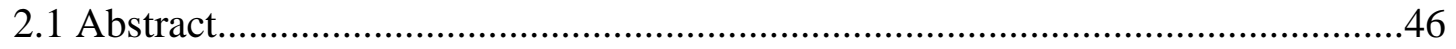

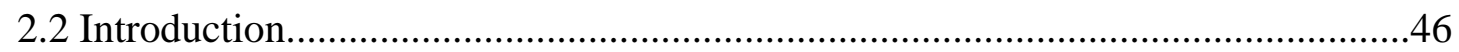

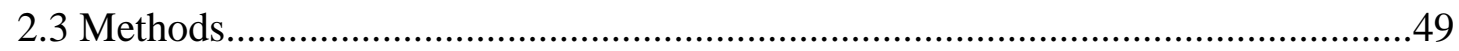

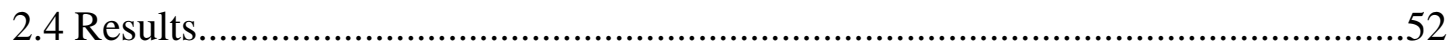

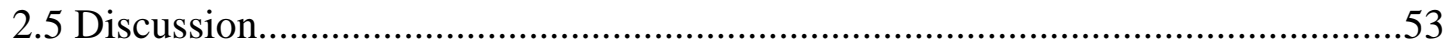

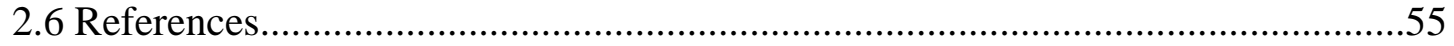

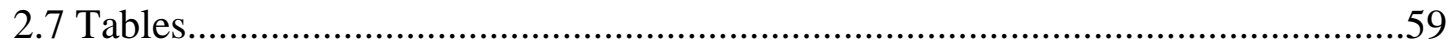

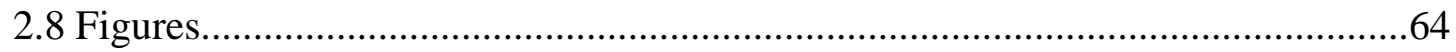

3. Capítulo 3: Co-occurrence patterns between tadpoles and predaceous insects in ponds: an approach using null models.................................................................66

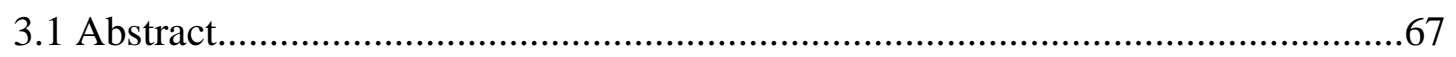

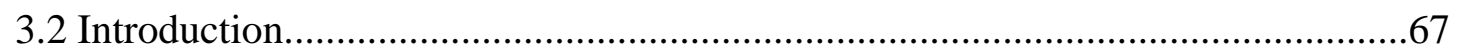

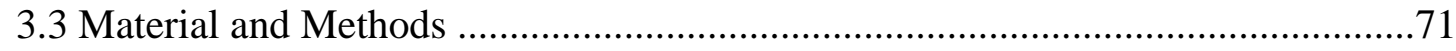

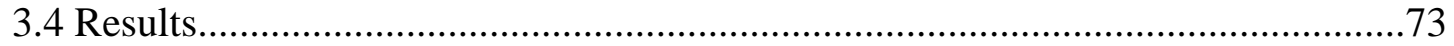




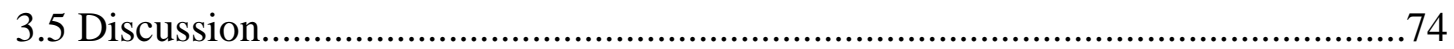

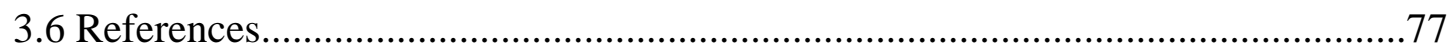

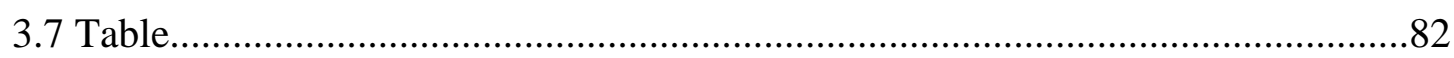

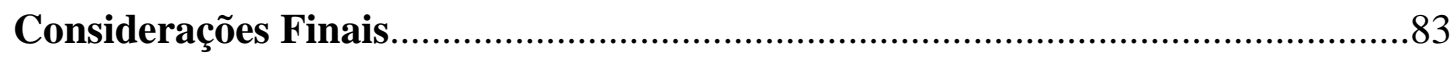

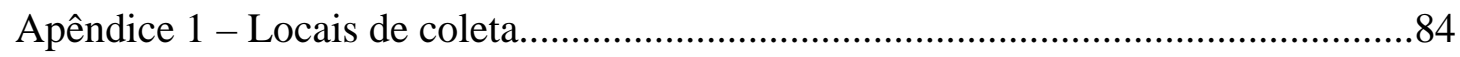

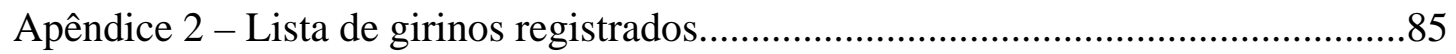

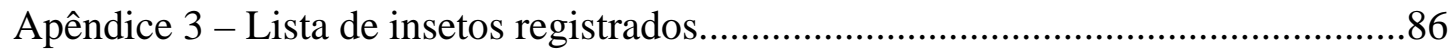




\section{RESUMO GERAL}

Girinos são um importante componente de ecossistemas de água doce e, ao longo dos últimos trinta anos, vêm sendo utilizados como modelos para testar hipóteses em ecologia de comunidades. O conjunto de informações disponível atualmente sugere que a presença de predadores influencia a abundância e o uso de hábitat por girinos e, conseqüentemente, a estrutura da comunidade. O objetivo deste estudo foi determinar o uso de recursos e investigar a influência de predadores na distribuição espacial de espécies e na estrutura de comunidades de girinos. As principais questões deste estudo foram: 1) qual o papel dos fatores abióticos na estruturação de comunidades de girinos?; 2) qual o grau de sobreposição de nicho entre as espécies nos três principais eixos de recursos: tempo (ocorrência sazonal), alimento e espaço (hábitat)?; 3) os girinos apresentam um padrão de distribuição não-aleatório em relação aos predadores? As amostragens tiveram frequiência mensal com coletas simultâneas de girinos e insetos predadores. Na caracterização dos corpos d'água foram utilizados dez descritores ambientais. Para determinar as guildas de espécies com relação ao uso de hábitat e ocorrência mensal foi implementada, respectivamente, uma análise de agrupamento e de ordenação por escalonamentro multidimensional não métrico. Para investigar a associação entre a abundância de girinos e os gradientes ambientais foi usada uma análise de correspondência canônica. A partilha de recursos entre girinos foi analisada utilizando-se uma análise de sobreposição de nicho em conjunto com um modelo nulo, considerando como eixos de recursos a ocorrência mensal, ocorrência nas poças e os itens alimentares. A análise da co-ocorrência pareada de girinos e predadores foi efetuada utilizando-se um modelo nulo. Os principais resultados foram que os gradientes de cobertura de dossel e hidroperíodo das poças foram os principais responsáveis pela variação da abundância das espécies nos corpos d'água amostrados. 
Os girinos das diferentes espécies de anuros distribuíram-se ao longo desses dois gradientes ambientais, com espécies marcadamente restritas aos extremos de variação de ambos os gradientes. Houve pouca partilha sazonal entra as especies, sendo que a maioria ocorreu na estação quente e chuvosa. A dieta foi o eixo de recurso no qual houve a maior sobreposição entre as espécies, enquanto que a ocorrência temporal e espacial foram os eixos de recurso mais partilhados pelas espécies. A maioria das associações entre girinos e insetos predadores foi aleatória $(96,3 \%)$, enquanto $2,6 \%$ foi negativa e $1,1 \%$ foi positiva. Estes resultados sugerem que insetos aquáticos predadores não influenciam o uso de hábitat por girinos na escala espacial estudada.

Palavras-Chave: estrutura de comunidades, anfíbios, insetos aquáticos, uso de recursos, nicho ecológico, fenologia, interação predador-presa, seleção de hábitat. 


\section{GENERAL ABSTRACT}

Tadpoles are an important component of freshwater ecossystems and in the last thirty years has been used as model organisms to test hypothesis in community ecology. The data currently available suggest that the presence of predators influences the abundance and habitat use by tadpoles and, consequently the community structure. The aims of this study were to establish how tadpoles divide resources and to investigate the influence of predators on species distribution and on community structure of tadpoles. The main questions were: 1) What is the role of abiotic factors in the community structure?; 2) What is the extent of niche overlap among species, considering the three main resource axes: time (seasonal occurrence), diet items and space (macrohabitat)?; 3) Tadpoles exhibit a non-random distribution pattern in relation to predaceous insects? We conducted monthly samplings to collect tadpoles and predaceous insects. We also used 10 environmental descriptors to characterize the water bodies. To recognize species guilds in relation to habitat use and monthly occurrence, we employed respectively a cluster analysis and a n-MDS, respectively. To investigate the association between species abundance and environmental gradients we used a canonical correspondence analysis. The resource partitioning among tadpoles was analyzed using a null model, considering as recource axes monthly occurrence, pond occupancy and diet items. The pair-wise co-occurrence analysis between tadpoles and predaceous insects was carried out using a null model. Our main findings demonstrate that forest canopy cover and pond hydroperiod were the main factors influencing species abundance along water bodies sampled. There was a species sorting along these two environmental gradients, with species restricted to both ends of these continuums. There was a high overlap in seasonal occurence of anuran larvae, being the majority of species occuring in the rainy season. We found 
that diet was the resource axis in which there was the higher overlap, whereas temporal occurrence and pond occupancy were more partitioned among tadpoles. We found that the majority of associations between tadpoles and insects were random (96.3\%), whereas $2.6 \%$ were negative and $1.1 \%$ was positive. These results suggest that predaceous aquatic insects do not influence the habitat use by anuran tadpoles in the spatial scale studied.

Key-words: Community structure, aquatic insects, amphibians, tadpoles, resource partitioning, ecological niche, phenology, predator-prey interactions, habitat selection. 


\section{INTRODUÇÃ̄ GERAL}

Uma comunidade ecológica é composta pelo conjunto de populações de espécies que co-ocorrem no espaço e no tempo (Begon et al., 2006). Os objetivos centrais da ecologia de comunidades são entender as razões que determinam a composição, abundância e distribuição dos organismos na natureza, além dos processos que mantêm a biodiversidade (Morin, 1999; Begon et al., 2006). No entanto, devido à complexidade envolvida em se estudar comunidades ecológicas, os pesquisadores muitas vezes enfocam somente a gama de interações que ocorrem entre organismos representantes de um mesmo táxon, ou seja, uma assembléia (sensu Fauth et al., 1996; Magurran, 2004).

Os padrões de uso e sobreposição de recursos são de particular interesse para ecólogos de comunidade, na medida em que a sua análise pode revelar aspectos da coexistência de espécies em uma assembléia. Esse tipo de abordagem têm mais probabilidade de revelar características importantes da coexistência de espécies quando se examina os padrões de utilização de recurso entre grupos de espécies relacionadas taxonomicamente, já que elas compartilham muitas das dimensões do nicho (Tokeshi, 1999). O termo 'partilha de recursos' refere-se às diferenças no uso de recursos por espécies ecologicamente similares (Abrams, 1983). Espécies podem coexistir partilhando os recursos espacial (e.g. uso diferencial de microhábitat) e temporalmente (utilizando recursos limitados em diferentes épocas do ano) como forma de reduzir a competição (Roughgarden, 1976).

O conceito de nicho ecológico tem se modificado desde as proposições iniciais do termo por Grinnell e Elton, que levavam em conta o espaço ocupado por uma espécie no ambiente e os seus efeitos no ambiente. Posteriormente o conceito de nicho foi modificado por Hutchinson e passou a ser relativo à espécie, incorporando um espaço multidimensional que envolvia as condições bióticas e abióticas necessárias para a sua sobrevivência e reprodução (revisado em Schoener, 1989). No entanto, esses conceitos eram de difícil operacionalização e, nos últimos anos, muita atenção tem sido dada para reformular o conceito de nicho ecológico de modo a incluir um abordagem "mecanística" (Tilman, 1982) e fornecer hipóteses testáveis para explicar a coexistência de espécies em comunidades (Chase e Leibold, 2003). Atualmente, o conceito de nicho ecológico diz respeito aos requisitos ambientais essenciais para a sobrevivência da espécie, bem como ao seu impacto no ambiente, 
incluindo interações interespecíficas, compreendendo um espaço que incorpora quatro eixos: recursos, tempo, espaço e predadores (Leibold, 1995; Chase e Leibold, 2003)

O estudo de comunidades de anfíbios anuros no Brasil tem histórico recente e muito esforço tem sido direcionado para a observação e a descrição de padrões de distribuição de espécies. Apesar de desejável, este tipo de abordagem deve ser complementada por estudos embasados em teorias e que testam hipóteses a respeito de como estão estruturadas as comunidades na natureza (Andrade et al., 2007). Os girinos de anfíbios anuros compõem um dos elementos mais notáveis em ecossistemas de água doce. Além disso, constituem-se ótimos modelos para entender de que modo processos como competição (Wilbur, 1982; Morin, 1983), predação (Hero, 1991; Gascon, 1992; Azevedo-Ramos et al. 1999), fatores abióticos (AzevedoRamos et al. 1999) e fenômenos estocásticos (Wilbur, 1987) interagem para regular a diversidade e a estrutura de comunidades animais (Wilbur, 1997). Diversos autores (e.g. Toft, 1985; Gascon, 1991; Rossa-Feres e Jim, 1996; Eterovick e Sazima, 2000) ressaltam que os padrões de ocorrência e de uso de recursos pelos girinos de anfíbios anuros resultam de uma complexa interação entre fatores bióticos e abióticos os quais, freqüentemente, operam em escalas diferentes. Esta constatação evidencia a necessidade de se relacionar os padrões de riqueza e de partilha de recursos com os processos causais, sejam eles bióticos (e.g. competição, predação, facilitação) ou abióticos (complexidade estrutural do hábitat, clima, hidroperíodo de corpos d'água).

Diversos fatores contribuem para a manutenção da estrutura e organização de comunidades de girinos. Entre eles, ressaltam-se interações interespecíficas (e.g., competição, Wilbur, 1987; predação, Heyer et al., 1975; Gascon, 1995), fatores abióticos, como aspectos físico-químicos da água, isolamento, hidroperíodo e o tamanho dos corpos d’água (Rossa-Feres e Jim, 1996; Alford, 1999; Eterovick e Sazima, 2000), além de aspectos da paisagem, como a disponibilidade de hábitats reprodutivos (Zimmerman e Bierregaard, 1986). Outros estudos envolvendo comunidades de girinos demonstraram partilha de hábitat (Inger et al., 1986), microhábitat (Gascon, 1995; Rossa-Feres e Jim, 1996; Eterovick e Barros, 2003), dieta (Alford, 1999; Rossa-Feres et al., 2004) e distribuição temporal (Heyer, 1974; Santos et al., 2007). A dinâmica temporal de girinos pode influenciar o surgimento de interações intra e interespecíficas. Alford (1989) demonstrou, utilizando experimentos com poças artificiais, que a variação fenológica de um predador vertebrado 
influenciou fortemente a composição e aptidão de girinos por meio da redução do número de recém-metamorfoseados (Wilbur e Alford, 1985).

Dentre os processos bióticos, a predação tem sido considerada como um dos fatores de maior impacto tanto na evolução quanto na estrutura de comunidades (Connell, 1975; Sih et al., 1985). Particularmente em girinos, tem-se enfatizado o papel de predadores em diminuir ou impedir a competição entre espécies, por alterar a distribuição espacial e as abundâncias relativas, sendo ainda considerados os principais determinantes da composição e riqueza de espécies (Heyer et al., 1975; Morin, 1983; Gascon, 1995; Alford, 1999). Por exemplo, a ocorrência de peixes em corpos d'água permanentes, mesmo em baixa densidade, exerce forte pressão de predação sobre as populações de girinos (Azevedo-Ramos et al., 1999; Hero et al., 2001) podendo mesmo excluir localmente a população de uma espécie. No entanto, predadores invertebrados parecem ter certa influência na estrutura de comunidades de girinos. Gascon (1995) encontrou que larvas de libélula eram também capazes de exlcuir localmente populações de girinos de corpos d'água na Amazônia central.

Como apontado por Alford (1999), para uma completa compreensão da autoecologia de girinos são necessárias informações como tipo de item alimentar, fenologia reprodutiva (já que esta pode determinar o surgimento de interações entre competidores e predadores) e estrutura do hábitat, além de dados sobre abundância de potenciais predadores e competidores. Tendo isso em vista, pretendemos nesta dissertação abordar estes aspectos de maneira a alicerçar um amplo entendimento das interrelações existentes nas comunidades de girinos habitantes de ambientes lienticos da Floresta Atlântica Brasileira.

\section{Da organização desta dissertação}

Esta dissertação está organizada em três capítulos de maneira a satisfazer cada um dos objetivos propostos, organizar e facilitar o entendimento dos resultados obtidos. No primeiro capítulo é investigado o papel dos fatores abióticos na determinação da riqueza e da abundância de girinos em escala local. O segundo capítulo compreende a análise do nicho multidimensional, envolvendo os três principais eixos de recursos: espaço, tempo e alimento, para avaliar qual(is) recurso(s) possibilita(m) maior partilha e portanto quais os processos associados ao uso desse(s) seriam os principais responsáveis pela coexistência das espécies. Por fim o terceiro 
capítulo apresenta os resultados da análise de co-ocorrência de girinos e insetos predadores em poças, para analisar se insetos predadores influenciam o uso de hábitat por girinos.

\section{Nota taxonômica}

A anurofauna do Planalto da Bocaina, onde este estudo foi realizado, tem sido estudada desde os meados do século passado, com os trabalhos pioneiros de Werner C. A. Bokermann e Adolpho e Bertha Lutz. Além disso coletas freqüentes de material herpetológico foram feitas ao longo das quatro últimas décadas por vários pesquisadores, incluindo W. R. Heyer, A. Cardoso, D. Cannatella, Célio F. B. Haddad e um recente estudo publicado por Serafim et al. (2008). Essas explorações fizeram com que 17 espécies de anfíbios anuros fossem descritas a partir de material coletado na Bocaina (localidade-tipo), são elas: Aplastodiscus callipygius, Bokermannohyla ahenea, Bokermannohyla clepsydra, Brachycephalus vertebralis, Crossodactylus dispar, Cycloramphus eleutherodactylus, Cycloramphus granulosus, Ischnocnema pusilla, Megaelosia bocainensis, Paratelmatobius gaigae, Phasmahyla cochranae, Physalaemus barrioi, Scinax atratus, Scinax ariadne, Scinax flavoguttatus, Scinax squalirostris e Vitreorana eurygnatha (Frost, 2009). No entanto, apesar de ter sido extensamente explorada, a área ainda surpreende, já que muitas das espécies que foram descritas são classificadas como Deficientes em Dados, segundo a IUCN, com muitas informações básicas sobre história natural indisponíveis. Ainda hoje muitas formas novas são freqüentemente coletadas (Haddad, C.F.B. com. pess.). Este conhecimento fragmentado resulta muitas vezes em dificuldades na identificação de material proveniente da área. A lista de espécies fornecida por este estudo foi baseada, além da análise da morfologia dos girinos, na identificação das formas adultas das larvas coletadas. As abreviações aff. (affinis) e gr. (grupo) utilizadas dizem respeito à formas que ainda não foram formalmente descritas por taxonomistas e que, respectivamente, são próximas a uma determinada espécie ou tem características que permitem considerá-la como pertencente a um determinado grupo de espécies. Uma das espécies coletadas por nós (Scinax sp. (aff. alter)) foi somente representada por dois exemplares (doubleton), portanto, por falta de réplicas, esta espécies não foi incluída em nenhuma das análises apresentadas a seguir. 


\section{口BJETIVD GERAL}

Determinar o padrão de utilização de recursos em assembléias de girinos, além de avaliar de que maneira a co-ocorrência entre girinos e predadores afeta a estrutura da comunidade.

\section{口BJETIVDS ESPECÍFIC口S}

1. Investigar a influência dos fatores abióticos na riqueza e na abundância de girinos habitantes de poças;

2. Determinar o grau de sobreposição de nicho considerando três eixos de recurso: tempo, espaço e alimento;

3. Testar se insetos predadores restringem o uso de hábitat por girinos em escala de assembléias. 


\section{LITERATURA CITADA}

Abrams, P. A. 1983. The theory of limiting similarity. Annual Review of Ecology, Evolution and Systematics 14:359-376.

Alford, R. A. 1989. Variation in predator phenology affects predator performance and prey community Ecology 70:206-219.

Alford, R. A. 1999. Ecology: resource use, competition and predation, p. 240-278. In: Tadpoles, the biology of anuran larvae. R. W. McDiarmid and R. Altig (eds.). University of Chicago Press, Chicago.

Andrade, G. V., P. C. Eterovick, D. C. Rossa-Feres, e L. Schiesari. 2007. Estudos sobre girinos no Brasil: histórico, conhecimento atual e perspectivas, p. 127-145. In: Herpetologia no Brasil II. L. B. Nascimento, A. T. Bernardes, and G. A. Cotta (eds.). PUC-MG, Fundação Biodiversitas e Fundação Ezaquiel Dias, Belo Horizonte.

Azevedo-Ramos, C., W. E. Magnusson, e P. Bayliss. 1999. Predation as the key factor structuring tadpole assemblages in a savanna area in central Amazonia. Copeia 1999:22-33.

Begon, M., C. R. Townsend, e J. L. Harper. 2006. Ecology: from individuals to ecossystems. Blackwell Science, Oxford.

Chase, J. M., e M. A. Leibold. 2003. Ecological niches, linking classical and contemporary approaches. Chicago University Press, Chicago.

Connell, J. H. 1975. Some mechanisms producing structure in natural communities: a model and evidence from field experiments, p. 460-490. In: Ecology and evolution of communities. M. L. Cody and J. M. Diamond (eds.). Belknap, Cambridge.

Eterovick, P. C., e I. Sazima. 2000. Structure of an anuran community in a montane meadow in southeastern Brazil: effects of seasonality, habitat, and predation. Amphibia-Reptilia 21:439-461.

Eterovick, P. C., e I. S. Barros. 2003. Niche occupancy in south-eastern Brazilian tadpole communities in montane-meadow streams. Journal of Tropical Ecology 19:439-448.

Fauth, J. E., J. Bernardo, M. Camara, W. J. Resetarits, Jr., J. V. Buskirk, e S. A. Mccollum. 1996. Simplifying the jargon of community ecology: a conceptual approach. American Naturalist 147:282-286.

Frost, D. R. 2009. Amphibian Species of the World: an Online Reference. Version 5.3 (12 February, 2009). Electronic Database accessible at http://research.amnh.org/herpetology/amphibia/ American Museum of Natural 
History, New York, USA.

Gascon, C. 1991. Population- and community-level analyses of species occurrences of central amazonian rainforest tadpoles. Ecology 72:1731-1746.

Gascon, C. 1995. Tropical larval anuran fitness in the absence of direct effects of predation and competition. Ecology 76:2222-2229.

Hero, J.-M., W. E. Magnusson, C. F. D. Rocha, e C. P. Catterall. 2001. Antipredator defenses influence the distribution of amphibian prey species in the central Amazon Rain Forest. Biotropica 33:131-141.

Heyer, W. R. 1974. Niche measurements of frog larvae from a seasonal tropical location in Thailand. Ecology 55:651-656.

Heyer, W. R., R. W. Mcdiarmid, e D. L. Weigmann. 1975. Tadpoles, predation and pond habitat in the tropics. Biotropica 7:100-111.

Inger, R. F., H. K. Voris, e K. J. Frogner. 1986. Organization of a community of tadpoles in rain forest streams in Borneo. Journal of Tropical Ecology 2:193-205.

Leibold, M. A. 1995. The niche concept revisited: mechanistic models and community context. Ecology 76:1371-1382.

Magurran, A. E. 2004. Measuring biological diversity. Blackwell publishing, Oxford.

Morin, P. J. 1983. Predation, competition, and the composition of larval anuran guilds. Ecology 53:119-138.

Morin, P. J. 1999. Community ecology. Wiley-Blackwell, Oxford.

Rossa-Feres, D. C., e J. Jim. 1996. Distribuição espacial em comunidades de girinos na região de Botucatu, São Paulo (Amphibia, Anura). Revista Brasileira de Biologia 56:309-316.

Rossa-Feres, D. C., J. Jim, e M. G. Fonseca. 2004. Diets of tadpoles from a temporary pond in southeastern Brazil (Amphibia, Anura). Revista Brasileira de Zoologia 21:745-754.

Roughgarden, J. 1976. Resource partitioning among competing species - a coevolutionary approach. Theoretical population biology 9: 388-425

Santos, T. G., D. C. Rossa-Feres, e L. Casatti. 2007. Diversidade e distribuição espaçotemporal de anuros em região com pronunciada estação seca no sudeste do Brasil. Iheringia 97:37-49.

Schoener, T. W. 1989. Ecological niche, p. 79-113. In: Ecological concepts. J. M. Cherret (ed.). Blackwell Scientific, Oxford.

Serafim, H., S. Ienne, P. J. P. Cicchi, e J. Jim. 2008. Anurofauna de remanescentes de 
floresta Atlântica do município de São José do Barreiro, estado de São Paulo, Brasil. Biota Neotropica 8(2): 69-77.

Sih, A., P. Crowley, M. A. McPeek, J. Petranka, e K. Strohmeier. 1985. Predation, competition, and prey communities: a review of field experiments. Annual review of ecology and systematics 16:269-311.

Tilman, D. 1982. Resource competition and community structure. Princeton University Press, Princeton.

Toft, C. A. 1985. Resource partitioning in amphibians and reptilies. Copeia 1985:1-21.

Tokeshi, M. 1999. Species coexistence, ecological and evolutionary perspectives. Blackwell Science, Oxford.

Wilbur, H. M. 1982. Competition between tadpoles of Hyla femoralis and Hyla gratiosa in laboratory experiments. Ecology 63:278-282.

Wilbur, H. M. 1987. Regulation of structure in complex systems: experimental temporary pond communities. Ecology 68:1437-1452.

Wilbur, H. M. 1997. Experimental ecology of food webs: complex systems in temporary ponds. Ecology 78:2279-2302.

Wilbur, H. M., e R. A. Alford. 1985. Priority effects in experimental pond communities: responses of Hyla to Bufo and Rana. Ecology 66:1106-1114.

Zimmerman, B. L., e R. O. Bierregaard. 1986. Relevance of the equilibrium theory of island biogeography and species-area relations to conservation with a case from Amazonia. Journal of Biogeography 13:133-143. 
The role of abiotic factors in structuring assemblages of pond-dwelling tadpoles in the Brazilian Atlantic Rain Forest

Diogo B. Provete ${ }^{1 *}$, Michel V. Garey ${ }^{1}$, Denise de C. Rossa-Feres ${ }^{1}$, Itamar A. Martins ${ }^{2}$

${ }^{1}$ Laboratório de Ecologia Animal, Departamento de Zoologia e Botânica, Instituto de Biociências, Letras e Ciências Exatas (IBILCE), UNESP-Universidade Estadual Paulista, R. Cristóvão Colombo, 2265, 15054-000, São José do Rio Preto-SP, Brasil, dbprovete@gmail.com; michel_bio@yahoo.com.br; denise@ibilce.unesp.br.

${ }^{2}$ Laboratório de Zoologia, Departamento de Biologia, Universidade de Taubaté, Av. Tiradentes, 500, 12030-180, Tabuaté-SP, Brasil, istama@uol.com.br

*Author to whom the proofs should be sent: dbprovete@gmail.com.

Running Title: Tadpole community structure in the Brazilian Atlantic Rain Forest

** Manuscrito escrito nas normas do periódico Journal of Tropical Ecology (ISSN 0266-467)

Key-words: Brazilian Atlantic Forest, tadpoles, anurans, abundance, hydroperiod, canopy cover, gradient analysis, community structure, phenology, species coexistence. 


\section{Abstract}

Species abundance and richness are two of the most basic descriptors of ecological communities. The aim of this study was to evaluate how abiotic factors influence species richness and abundance of tadpoles across water bodies in an area of Atlantic Rainforest in Southeastern Brazil. Tadpoles were collected in 13 ponds and swamps in a highland environment. Abiotic parameters, such as surface vegetation cover, depth, $\mathrm{pH}, \mathrm{DO}$, turbidity, conductivity and pond size were recorded for each water body. The water bodies also differed in two important environmental gradients: hydroperiod and canopy cover. As the major result, we found forest canopy cover and hydroperiod to be mainly responsible for the variation in the species abundance and richness of tadpoles along water bodies. Tadpole species were sorted along these two environmental gradients, with species restricted to its both ends. There was little seasonal partitioning among species, with the majority of species occurring in the wet and warm season. Only air temperature influenced the monthly abundance of species. Interestingly, endemic species were the most abundant ones in the study area, a fact that argues against current theories linking geographic range and species abundance. This is the first study in the southern Hemisphere to report hydroperiod and canopy cover as main factors structuring tadpole assemblages.

\section{INTRODUCTION}

One of the main goals of community ecology is to understand the causes that determine the number of species in an area (Morin 1999). This research field has undergone deep changes in the last decade that are still under course, largely due to neutral theories that incorporate ecological drift, random migration and random 
speciation processes to explain patterns of species abundance and richness in ecological communities (e.g., Bell 2000, Hubbel 2001). On the other hand, there are attempts to embody a new perspective to key concepts in ecology, such as the ecological niche (Chase \& Leibold 2003, Leibold 1995). Recently, these two approaches, previously viewed as opposed to one another, are leading to a synthesis, that incorporates demographic processes (natality, mortality, immigration and emigration) along with processes based on differential resource use (e.g., Adler et al. 2007, Tilman 2004).

Species richness at local scales can be affected by historical processes, environmental filtering, interspecific interactions, and stochastic processes (Ricklefs 1987, 2004, Tokeshi 1999). Historical processes include regional species richness (Ricklefs 2004), spatial heterogeneity (McCoy \& Bell 1991), resource availability and differential resource allocation (Tilman \& Pacala 1993, Tokeshi 1999), and productivity (Mittelbach et al. 2001). The interspecific interactions include the intensity of predation and the density of competidors (Sih et al. 1985). Lastly, stochastic factors include colonization sequence, perturbation regime (Tokeshi 1999), and environmental fluctuations (Wolda 1987).

The temporal distribution of species is related to the sequence that species join the community; this phenonenon can greatly influence community assembly and species interactions (Morin 1999). Species arrive at communities at a sequence reflecting their differences in breeding phenology, and thus play an important role in determining the invasion success of a species and the outcome of interspecific interactions (Wilbur \& Alford 1985). Differences in timing of arrival are frequently interpreted as a strategy to decrese competitive interactions or simply an 
individualistic response by species to the changing enviroment (Lawler \& Morin 1993).

Gradients of changing environments, such as temperature, moisture or resource availability are a good framework for testing theories about communities (Wellborn et al. 1996). In addition, study of species abundance distributed along gradients can help understand the role of local determinism in regulating species diversity (Dunson \& Travis 1991, Ricklefs 2004). Two gradients in freshwater habitats have been regarded as strongly influencing species richness, abundance and spatial distribution: hydroperiod and canopy cover. Hydroperiod has been suggested to largely influence freshwater communities, including amphibians in several regions (Skelly 1997, Wellborn et al. 1996, Werner et al. 2007). Canopy cover has been showed to be an important variable in affecting distribution of amphibian species along landscapes (Werner et al. 2007) and a ubiquitous variable affecting freshwater taxa (e.g., McCauley et al. 2008). Closed-canopy areas tend to show low temperature, low solar incidence, low primary productivity, high dissolved oxygen, reduced survivorship, and low quality food resources (Schiesari 2006, Skelly et al. 2002, Werner \& Glennemeier 1999). However, the influence of these factors in the development and growing of tadpoles can vary interspecifically (Schiesari 2006).

Studies involving tadpole communities demonstrate that space partitioning is common at different scales. Tadpole species can occupy different habitats (Inger et al. 1986) and microhabitats (Eterovick \& Barros 2003, Gascon 1995, Rossa-Feres \& Jim 1994). In addition, temporal segregation among amphibian species seems to be common (Heyer 1974, Santos et al. 2007). However, the importance of these resource axes seems to vary among sites and according to species composition of communities. This pattern can be attributed to morphological differences among tadpoles, which 
enable them to occupy different habitats and microhabitats (reviewed in Duellman \& Trueb 1994). In addition, the temporal segregation reflects the phenology of adults, whose reproduction is determined by physiological and environmental factors (Wiest 1982).

The aims of this study was to analyze how local abiotic factors influence the variation in abundance and richness of tadpole species inhabiting ponds and swamps in a highland Atlantic Forest environment in Southeastern Brazil. We specifically addressed three major questions: 1) How the seasonal variation in the climatic variables (rainfall and air temperature) affects the abundance and richness of tadpole species throughout the year?; 2) How gradients of canopy cover and hydroperiod affect tadpole species abundance, diversity, and spatial distribution; 3) How the global abundance of tadpole species is influenced by abiotic factors?

\section{METHODS}

\section{Study site}

This work was carried out in the Serra da Bocaina National Park (PNSB, hereafter) $\left(22^{\circ} 44^{\prime} \mathrm{S}, 44^{\circ} 37^{\prime} \mathrm{W}\right)$, localized at the boundary between the states of São Paulo and Rio de Janeiro in southeastern Brazil. The PNSB comprises presently an area of 104.000 ha (Fig. 1) and is regarded as one of the main remnants of the Atlantic Rain Forest (sensu Ab'Saber 1977, Ribeiro et al. 2009) in southeastern Brazil, bearing protected areas of dense tropical rain forest, highland mixed tropical rain forest and highland grasslands (Eiten 1992). Our sampling was concentrated on the Bocaina highlands (1500 m a.s.1.), in the municipality of São José do Barreiro, state of São Paulo. In this region, the climate according to the Köppen-Geiger classification (Peel 
et al. 2007) is of the type Cwb (humid subtropical highland), with moderated temperatures, dry winters (between April and September) and warm summers (from October to March). The annual rainfall varies between 400 and $2100 \mathrm{~mm}$, with mean annual temperature of $22^{\circ} \mathrm{C}$. The relative humidity does not vary too much, with mean indexes between $77 \%$ and $82 \%$.

\section{Sampling procedures}

We sampled 13 water bodies with different morphologies. The water bodies comprised: one temporary pond in woodlands (PT5), two permanent ponds in open areas (PP3 and PP4), two swamps in open areas (BP2 and BP5), four permanents ponds in woodlands (AP1, AP2, PP1, and PP2), three temporary ponds in woodlands (PT1, PT2, and PT3), and one swamp in woodlands (BP9) (veja imagens no Apêndice 1). Each water body was sampled once a month, between July 2008 and June 2009 . Tadpoles were sampled using a wired deep net ( $3 \mathrm{~mm}$ of mesh) passed along the entire extent of the margins of water bodies (Shaffer et al. 1994, see also Skelly \& Richardson 2010). Tadpoles were fixed in the field with $10 \%$ formalin. The identification followed identification keys and direct comparisons with published descriptions. When identification was not possible using this means, we reared tadpoles in aquaria until metamorphose, feeding them with commercial fish rations. In addition, adult anurans were acoustically monitored monthly in each water body.

\section{Abiotic parameters}

The characteristics of the water bodies were assessed using two approaches. This information was recorded between August 2008 and January 2009 and was assumed not to vary along the remaining of the sampling period. We recorded the 
physic-chemical characteristics of water bodies, namely: mean conductivity ( $\mu \mathrm{s} / \mathrm{cma})$, mean dissolved oxygen $(\mathrm{mg} / \mathrm{l})$, mean $\mathrm{pH}$, mean temperature $\left({ }^{\circ} \mathrm{C}\right)$, and mean turbidity using a Horiba U-10 multiparameter water quality checker. We also measured other variables related to the morphology of water bodies, such as: months with standing water, surface area $\left(\mathrm{m}^{2}\right)$, maximum depth $(\mathrm{m})$, percentage of floating vegetation on the water surface, and percentage of canopy cover (Table 1). The last two variables were estimated visually by dividing the water surface in quadrants and estimating the percentage of surface covered by vegetation and the surface covered by the canopy. Daily air temperature and rainfall volume were obtained, respectively, from the PNSB staff and from the Bananal station, about $28 \mathrm{Km}$ apart from the study site, $460 \mathrm{~m}$ a.s.l.

\section{Statistical analyses}

Variation in species diversity among sites was analyzed using the parametric Fisher's $\alpha$ index of diversity, attached to a confidence interval. The diversity index $\alpha$ is a parameter of the log series model of species abundance distribution (Magurran 2004). This index has many advantages comparatively to the traditional used indices of Simpson and Shannon-Wiener, since it is independent of sample size and can be used even when the data do not fit the log series distribution (Magurran 2004). We also used the Pielou J' index to measure the evenness across water bodies (Pielou 1975). These analyses were carried out in vegan package of the R software v. 2.10.0 (R Development Core Team 2009).

To analyze the spatial variation in species abundance, we performed a hierarchical cluster analysis (Legendre \& Legendre 1998) using the pvclust package (Suzuki \& Shimodaira 2005) in the R software v. 2.10.0 (R Development Core Team 2009) that automatically computes p-values for all clusters. We also used the 
multiscale bootstrap resampling option that unlike common bootstrap analysis, in which the sample size remains constant and equal to the data matrix size, the sample size of the bootstrap sample ranged from smaller to larger sizes than the original matrix (Shimodaira 2004). In this situation, the p-value is estimated fitting to a theoretical curve obtained from the range of sizes. This p-value, called the approximately unbiased p-value (AU) by the pvclust package, is more accurate because it corrects the bias of the bootstrap probability value caused by a constant sample size (Shimodaira 2004). The agglomerative method used was UPGMA and the dissimilarity method was Pearson's correlation, which as a distance measure implements a calculation of the complement 1-r of Pearson's $r$ correlation across the variables (Legendre \& Legendre 1998).

The temporal variation in species composition along sampled months was analyzed using a non-metric multidimensional scaling (nMDS). The nMDS analysis attempts to reduce the objects in as few dimensions as possible, while preserving the distance among them, in doing so it preserves better the great distances instead of the small ones (Legendre \& Legendre 1998). Thus, this method is approprite to show similarities among objects in long gradients. How accurately the plot represents the original data matrix is expressed by the stress value, a value between 0.0 and 0.2 indicates a good representation. As the analysis can be run with any similarity or dissimilarity method, we chose a binary index of similarity (Jaccard). We did this because we can obtain a better perception of temporal patterns of tadpoles when we only take into account species occurrences, since abundance patterns of tadpoles are mainly shaped by a combination of historical and contemporary processes, such as reproductive modes of adult anurans. This analysis was performed in the software Past v. 1.97 (Hammer et al. 2001). To evaluate how monthly air temperature 
(independent variable) and rainfall (independent variable) variation affected the total abundance (dependent variable) and richness (dependent variable) of tadpoles during the study period, we performed a multiple regression analysis (Quinn \& Keough 2002). The regression analysis was carried out in the $R$ software v. 2.10 .0 ( $R$ Development Core Team 2009).

The variation in species abundance along environmental gradients was analyzed using a canonical correspondence analysis. Explanatory variables were included through a forward selection process that employs a randomization procedure to select only significant environmental variables with an $\alpha=5 \%$ (Legendre \& Legendre, 1998). The species abundances were log transformed. The analysis was performed in Canoco for Windows v. 4.5 (ter Braak \& Smilauer 1998).

We performed a model selection approach to identify the most appropriate statistical model that describes the global variation in abundance of species, considering the environmental variables. We employed the Akaike information criteria (AIC) to rank models that best support data (Burnham \& Anderson 2002).

\section{RESULTS}

We collected 29,040 tadpoles from 17 species (Table 2). The mean richness along water bodies was 5 ( $\pm 2.5 \mathrm{SD})$ species, ranging from 2 to 9 species. The most abundant species was Scinax sp. (aff. hayii) (7,027 tadpoles; $24.2 \%$ of the total), and the least abundant species was Bokermannohyla sp. (gr. circumdata) (12 tadpoles; $0.041 \%)$.

The permanent ponds were the most diverse ones. In addition, the most uneven assemblages were those closed-canopy water bodies (Fig. 2). Interestingly, the 
most uneven assemblages were dominated by tadpoles of two endemic species from the Bocaina highland: Bokermannohyla ahenea and Physalaemus barrioi, and Hypsiboas sp. (aff. polytaenius).

The analysis of temporal occupancy of water bodies showed that the majority of species was restricted to the warm and wet season (larger circle in Fig. 3), being Chiasmocleis sp. (aff. mantiqueira), Scinax squalirostris, and Physalaemus olfersii a grouping whose species were more abundant in the end of the rainy season (smaller circle in Fig. 3). The other species: B. gr. circumdata, Proceratophrys melanopogon, Rhinella icterica and Scinax sp. (aff. obtriangulatus) presented different periods of occurrence and demonstrated no clear pattern in relation to temporal occupancy of water bodies (Fig. 3). From climatic parameters, only air temperature affected species richness along the year $\left(\mathrm{r}^{2}=0.823 ; \mathrm{F}_{(2,9)}=21.05 ; P=0.0004\right.$; temperature Beta=0.635; $\mathrm{SE}$ beta=0.278; $\mathrm{t}=2.28 ; P=0.048 ;$ rainfall Beta=0.009; SE beta=0.006; $\mathrm{t}=1.579 ; P=$ 0.148). The species abundance was not influenced by any of the climatic parameters analyzed $\left(\mathrm{r}^{2}=0.516 ; \mathrm{F}_{(2,9)}=4.811 ; P=0.03 ;\right.$ temperature Beta=0.05; SE beta=0.37; $\mathrm{t}=0.15 ; P=0.07 ;$ rainfall Beta $=0.76 ; \mathrm{SE}$ beta $=0.37 ; \mathrm{t}=2.05 ; P=0.89)$.

The analysis of spatial variation of tadpole abundance (Table 3 ) showed that the assemblages could be split into two guilds: one inhabitant of temporary, closedcanopy ponds, composed of $C$. aff. mantiqueira, Dendropsophus microps, $P$. olfersii, Scinax sp. (aff. hayii). Another guild inhabitant of permanent water bodies in both open and forested areas was composed of B. ahenea, P. melanopogon, B. gr. circumdata, P. barrioi, Leptodactylus furnarius, Aplastodiscus perviridis, $S$. squalirostris, R. icterica, Scinax sp. (aff. duartei), H. aff. polytaenius, Dendropsophus minutus, and S. aff. obtriangulatus (Fig. 4). 
The gradient analysis recovered five main environmental variables that explained $77 \%$ of the variation in species abundance (Table 3; Fig. 5): percentage vegetation cover, hydroperiod, area of water bodies, conductivity, and water $\mathrm{pH}$. There are four recognized groups. The species $C$. aff. mantiqueira was the only species strongly associated with high values of conductivity, short hydroperiod, large area and high percentage of surface vegetation cover. Another three groups of species included: S. squalirostris, L. furnarius, P. barrioi, A. perviridis, S. aff. duartei, $R$. icterica, D. minutus, $H$. aff. polytaenius, which were associated to small water bodies, low percentage of surface vegetation cover, long hydroperiods, high values of $\mathrm{pH}$ and low conductivity; D. microps, $S$. aff. hayii, and $P$. olfersii, which were associated to large water bodies, high percentage of vegetation cover, low values of $\mathrm{pH}$, short hydroperiods, and high conductivity; S. aff. obtriangulatus, B. ahenea, B. gr. circumdata, and P. melanopogon, which were associated to small water bodies, low percentage of vegetation cover, long hydroperiods, high values of $\mathrm{pH}$, and low values of conductivity (Figure 5).

The best-supported model that explained the global variation in abundance of species included surface area of water bodies and percentage of canopy cover (Table 4).

\section{DISCUSSION}

Our main findings suggest that pond hydroperiod and canopy cover are playing a major role in shaping this tadpole community. The permanent ponds showed the highest diversity, those ponds were also dominated by endemic species from the Bocaina highland. We also found a high temporal overlap among species, 
with the majority occurring the wet and warm period of the year. However, only air temperature did affect tadpole species richness.

Pond hydroperiod seems to be very important in determining pond occupancy (Fig. 4). In our system, it seems that there is a species sorting along the hydroperiod gradient, with certain species restricted to temporary ponds and others restricted to permanent ones. Several authors (e.g. Heyer et al. 1975, Wilbur 1984) proposed that species richness presents a unimodal response to hydroperiod gradient. However, we found that species were associated to both extremes in hydroperiod, what account for life-history adaptations to inhabit water bodies with short, in contrast to those with long hydroperiods (Wilbur 1980), a result commonly found by other authors (e.g., Babbit et al. 2003, Semlitsch et al. 1996). Hydroperiod gradients are often correlated with a predation gradient (Skelly 1997, Wellborn et al. 1996), in which water bodies with longer hydroperiods hold populations of predatory fishes. However, we did not find any predatory fish in our study site (Provete et al. unpubl. ms.-Capítulo 3), thus predation pressure by fishes is not affecting water body occupancy by tadpoles. We also found a high species richness associated with long hydroperiod ponds (Fig. 4). Taken together, these results could explain our inability to find a unimodal response of species to hydroperiods.

Pond canopy cover influenced both spatial distribution and abundance of species, with species being restricted to closed- versus open-canopy areas. Canopy cover is known to largely influence freshwater taxa, including growth and developmental rate (Schiesari 2006, Skelly et al. 2002). This variation could explain the occurence of Chiasmocleis sp. (aff. mantiqueira) strongly associated to closedcanopy ponds. Schiesari (2006) working in ponds in southern Michigan, USA found that Lithobates sylvaticus was the only species tolerant to closed-canopy ponds. In our 
study system, $C$. aff. mantiqueira may be employing the same strategy: take advantage of the lower interspecific competition, but also could experience lower growth rate associated with these ponds. In addition, this species could benefit from breeding in closed-canopy ponds due to the very low abundance and richness of predaceous insects in those environments (McCauley et al. 2008, Provete et al. unpubl. ms.-Capítulo 3).

The Atlantic Forest presents the greatest diversity of reproductive modes of anurans, with 21 recognized modes, from which seven are exclusively found in this vegetation formation (Haddad \& Prado, 2005). This diversity can be attributed to the great variety of breeding sites available to anurans and the specialization of species in reproducing in these sites. In this work we sampled only standing water bodies, which can explain the low mean species richness found, compared to other studies in tropical regions (Duellman \& Trueb 1994). The assemblage of pond-dwelling tadpoles seems to be only part of the total richness of anurans found in the Bocaina highland, since about $54 \%$ of the species found in the area are pond-breeders, being the remaining composed of direct-developing frogs and stream-breeders (M.V. Garey, unpubl. data).

The fact that the most uneven assemblages were dominated by species with narrow geographic range apparently argues against the niche-based hypothesis proposed by Brown $(1984,1995)$ in which species with a small geographic range should be locally rare. However, the author also emphasizes that both evolutionary and ecological constraints can actually act to shape the relationship between abundance and distribution of species (Brown 1995). The species groups in which Physalaemus barrioi is included ( $P$. gracilis group) is composed of species that have a distribution restricted to high altitudes (Nascimento et al. 2005), thus it is possible 
that a phylogenetic component is involved in determining the local abundance of that species. The Atlantic Forest is a montainous region, like the Andes, where a recent study suggested allopatric speciation as the most important speciation mechanism in centrolenid frogs (Guyasamin et al. 2008). The tree frog B. ahenea is only known from the Bocaina highland, and it is probable that, although that area represents a suitable habitat (see Watkinson et al. 2003 for a review of relationships between habitat suitability and abundance), migration is extremely rare in this population (maybe because $B$. ahenea represents a recently diverged species), thus although very abundant, it is locally restricted.

Only air temperature was recovered as an important climatic factor influencing species richness in water bodies. This kind of result has been found in another area of temperate humid climate in Southern Brazil (Both et al. 2009). Canavero et al. (2009) also found that temperature influenced more strongly the temporal structure of anuran community than precipitation. These authors hypothesized that air temperature and not precipitation best represents seasonality, although this outcome can be scale-dependent (Canavero et al. 2009). Physiological constraints of adult amphibians (Duellman \& Trueb 1994), which can demonstrate species-specific responses to the environment (Alford 1999), may also be involved in constraining the activity of anurans to the warm period of the year. Water temperature strongly influence growth rate, time to reach metamorphosis and rates of metabolism of tadpoles, being temperatures around $25^{\circ} \mathrm{C}$ the most suitable for growth and metabolic processes (Ultsch et al. 1999). In addition, temperature seems to be the most dramatic feature influencing physiology, ecology and behaviour of tadpoles (reviewed in Ultsch et al. 1999). 
The majority of species in the studied community had its distribution restricted to the rainy season, from September to November: A. perviridis, B. ahenea, D. microps, H. aff. polytaenius, P. barrioi, S. aff. duartei, S. aff. hayii. Whereas Chiasmocleis sp. (aff. mantiqueira), P. olfersii, and S. squalirostris occurred in the end of the rainny season. The remaining species (B. gr. circumdata, L. furnarius, $P$. melanopogon, $R$. icterica, and $S$. aff. obtriangulatus) were those whose temporal distribution did not follow any recognizable pattern (Fig. 3). However, $R$. icterica noticeably had its peak of abundance in the dry season. Bufonids are generally found in shallow waters, which provide a high temperature and hence a high growth rate (Alford 1999). This could explain the high abundance of $R$. icterica in the dry season, when ponds are shallower.

Temporal partitioning is less viewed as a mechanism promoting species coexistence, but to reflect physiological constraints of species (Kronfeld-Schor \& Dayan 2003). Partitioning time could be also a result of trade-offs among species, since species have different resource allocation patterns in different times of the year (Tilman \& Pacala 1993). In addition, coexistence through time partitioning is possible when species tend to occur in periods of time in which it is a dominant competitor (Chesson 2000, Roughgarden 1976, Tilman \& Pacala 1993). Species inhabiting temporary ponds could also benefit from the resource pulse provided by these ponds, thus allowing quick population growth (Yang et al. 2008). In addition, species that use temporary ponds for breeding could only occur when this type of water body is available, though the high productivity of those water bodies can support a high number of species (Wilbur 1980).

The global model that best explained the species abundance included surface area of water bodies and canopy cover. Larger areas can support larger population 
sizes along with more types of microhabitats (Rosenzweig 1995, Tilman \& Pacala 1993), thus a positive correlation between area and species abundance is expected. In addition, small water bodies are more susceptible to drought (Werner et al. 2007) and are expected to support only species that can develop rapid enough to metamorphose before pond drying (Wellborn et al. 1996).

\section{LITERATURE CITED}

AB'SABER, A. N. 1977. Os domínios morfoclimáticos da América do sul - primeira aproximação. Geomorfologia 52:1-21.

ADLER, P.B., HILLERISLAMBERS, J. \& LEVINE, J. M. 2007. A niche for neutrality. Ecology Letters 10:95-104.

ALFORD, R. A. 1999. Ecology: resource use, competition and predation. Pp. 240278 in McDiarmid, R. W. \& Altig, R. (eds.). Tadpoles, the biology of anuran larvae. University of Chicago Press, Chicago.

BABBITT, K. J., BABER, M. J. \& TARR, T. L. 2003. Patterns of larval amphibian distribution along a wetland hydroperiod gradient. Canadian Journal of Zoology $81: 1539-1552$.

BELL, G. 2000. The distribution of abundance in neutral communities. American Naturalist 155(5):606-617.

BOTH, C., SOLÉ, M., SANTOS, T. G. \& CECHIN, S. Z. 2009. The role of spatial and temporal descriptors for Neotropical tadpole communities in southern Brazil. Hydrobiologia 624:125-138.

BURNHAM, K. P. \& ANDERSON, D. R. 2002. Model selection and multimodel inference: 
a practical information-theoretic approach (2 edition). Springer-Verlag, New York. 514 pp.

BROWN, J. H. 1984. On the relationship between abundance and distribution of species. American Naturalist 124(2):255-279.

BROWN, J. H. 1995. Macroecology. Chicago University Press, Chicago. 269 pp.

CANAVERO, A., ARIM, M. \& BRAZEIRO, A. 2009. Geographic variations of seasonality and coexistence in communities: The role of diversity and climate. Austral Ecology $34: 741-750$.

CHASE, J. M. \& LEIBOLD, M. A. 2003. Ecological Niches, linking classical and contemporary approaches. Chicago University Press, Chicago. 212 pp.

CHESSON, P. 2000. Mechanisms of maintenance of species diversity. Annual Review of Ecology and Systematics 31(1):343-366.

DUELLMAN, W. E. \& TRUEB, L. 1994. Biology of amphibians. Johns Hopkins University Press, Baltimore. 670 pp.

DUNSON, W. A. \& TRAVIS, J. 1991. The role of abiotic factors in community organization American Naturalist 138(5):1067-1091.

EITEN, G. 1992. Natural Brazilian vegetation types and their causes. Anais da Academia Brasileira de Ciências 64(Suppl. 1):35-65.

ETEROVICK, P. C. \& BARROS, I. S. 2003. Niche occupancy in south-eastern Brazilian tadpole communities in montane-meadow streams. Journal of Tropical Ecology 19:439-448.

GASCON, C. 1995. Tropical larval anuran fitness in the absence of direct effects of predation and competition. Ecology 76(7):2222-2229.

GUAYASAMIN, J. M., CASTROVIEJO-FISHER, S., AYARZAGÜENA, J., TRUEB, L. \& VILÀ, C. 2008. Phylogenetic relationships of glassfrogs 
(Centrolenidae) based on mitochondrial and nuclear genes. Molecular phylogenetics and evolution 48:574-595.

HADDAD, C. F. B. \& PRADO, C. P. A. 2005. Reproductive modes in frogs and their unexpected diversity in the Atlantic Forest of Brazil. BioScience 55(3):207-217.

HAMMER, Ø., HARPER, D.A.T., P. D. RYAN. 2001. PAST: Paleontological Statistics Software Package for Education and Data Analysis. Palaeontologia Electronica 4(1): 9.

HEYER, W. R. 1974. Niche measurements of frog larvae from a seasonal tropical location in Thailand. Ecology 55:651-656.

HEYER, W. R., MCDIARMID, R. W. \& WEIGMANN, D. L. 1975. Tadpoles, predation and pond habitat in the tropics. Biotropica 7(2):100-111.

HUBBEL, S. P. 2001. The unified neutral theory of biodiversity and biogeography. Princeton University Press, Princeton. 390 pp.

INGER, R. F., VORIS, H. K. \& FROGNER, K. J. 1986. Organization of a community of tadpoles in rain forest streams in Borneo. Journal of Tropical Ecology 2(3):193-205.

KRONFELD-SCHOR N. \& DAYAN T. 2003. Partitioning of time as an ecological resource. Annual Review of Ecology, Evolution and Systematics 34, 153-81.

LAWLER, S. P. \& MORIN, P. J. 1993. Temporal overlap, competiton, and priority effects in larval anurans. Ecology 74(1):174-182.

LEGENDRE, P. \& LEGENDRE, L. 1998. Numerical ecology (second English edition). Elsevier, Amsterdam. 853 pp.

LEIBOLD, M. A. 1995. The niche concept revisited: mechanistic models and community context. Ecology 76(5):1371-1382. 
MAGURRAN, A. E. 2004. Measuring biological diversity. Blackwell publishing, Oxford. $256 \mathrm{pp}$.

MCCAULEY, S. J., DAVIS, C. J., RELYEA, R. A., YUREWICZ, K. L., SKELLY, D. K. \& WERNER, E. E. 2008. Metacommunity patterns in larval odonates. Oecologia 158:329-342.

MCCOY, E. D. \& BELL, S. S. 1991. Habitat structure: the evolution of a complex topic. Pp. 281-299 in Bell, S. S., McCoy, E. D. \& Mushinsky, H. R. (eds.). Habitat structure, the physical arrangement of objects in space. Chapman and hall, London.

MITTELBACH, G. G., STEINER, C. F., SCHEINER, S. M., GROSS, K. L., REYNOLDS, H. L., WAIDE, R. B., WILLIG, M. R., DODSON, S. I. \& GOUGH, L. 2001. What is the observed relationship between species richness and productivity? Ecology 82(9):2381-2396.

NASCIMENTO, L. B., CARAMASCHI, U. \& CRUZ, C. A. G. 2005. Taxonomic review of the species groups of the genus Physalaemus Fitzinger, 1826 with revalidation of the genera Engystomops Jiménez-de-la-Espada, 1872 and Eupemphix Steindachner, 1863 (Amphibia, Anura, Leptodactylidae). Arquivos do Museu Nacional 63(2):297-320.

PEEL, M. C., FINLAYSON, B. L. \& MCMAHON, T. A. 2007. Updated world map of the Köppen-Geiger climate classification. Hydrology and Earth System Sciences 11:1633-1644.

QUINN, G. P. \& KEOUGH, M. J. 2002. Experimental design and data analysis for biologists. Cambridge University Press, New York. 557 pp. 
R Development Core Team. 2009. R: a language and environment for statistical computing. R Foundation for Statistical Computing, Vienna, Austria. Available at: http://www.R-project.org (accessed on 20 December 2009)

Ribeiro, M. C., MEtzGer, J. P., MARTEnSEN, A. C., POnZONi, F. J. \& HIROTA, M. M. 2009. The Brazilian Atlantic Forest: How much is left, and how is the remaining forest distributed? Implications for conservation. Biological conservation 142:1141-1153.

RICKLEFS, R. E. 1987. Community diversity: relative roles of local and regional preocess. Science 235:167-171.

RICKLEFS, R. E. 2004. A comprehensive framework for global patterns in biodiversity. Ecology letters 7(1):1-15.

ROSENZWEIG, M. L. 1995. Species diversity in space and time. Cambridge University Press, Cambridge. 436 pp.

ROSSA-FERES, D. C. \& JIM, J. 1994. Distribuição sazonal em comunidades de anfíbios anuros na região de Botucatu, São Paulo. Brazilian Journal of Biology 54(2):323-334.

SANTOS, T. G., ROSSA-FERES, D. C. \& CASATTI, L. 2007. Diversidade e distribuição espaço-temporal de anuros em região com pronunciada estação seca no sudeste do Brasil. Iheringia 97(1):37-49.

SCHIESARI, L. 2006. Pond canopy cover: a resource gradient for anuran larvae. Freshwater biology 51:412-423.

SEMLiTSCH, R. D., SCOTT, D. E., PECHMANN, J. H. K. \& GIBBONS, J. W. 1996. Structure and dynamics of an amphibian community, evidence from a 16year study of a natural pond. Pp. 217-248 in Cody, M. \& Smallwood, J. A. (eds.). Long-term studies of vertebrate communities. Academic Press, London. 
SHAFFER, H. B., ALFORD, R. A., WOODWARD, B. D., RICHARDS, S. J., ALTIG, R. \& GASCON, C. 1994. Quantitative sampling of amphibian larvae. Pp. 130-140 in Heyer, W. R., Donnelly, M. A., McDiarmid, R. W., Hayek, L.-A. C. \& Foster, M. (eds.). Measuring and monitoring biological diversity - Standard methods for amphibians. Smithsonian institution press, Washington.

SHIMODAIRA, H., 2004. Approximately unbiased tests of regions using multistepmultiscale bootstrap resampling. Annals of Statistics 32, 2616-2641.

SIH, A., CROWLEY, P., MCPEEK, M. A., PETRANKA, J. \& STROHMEIER, K. 1985. Predation, competition, and prey communities: a review of field experiments. Annual review of ecology and systematics 16:269-311.

SKELLY, D. K. 1997. Tadpoles communities. American Scientist 85(1):36-45.

SKELLY, D. K., FREIDENBURG, L. K. \& KIESECKER, J. M. 2002. Forest canopy and the performance of larval amphibians. Ecology 83(4):983-992.

SKELLY, D. K. \& RICHARDSON, J. L. 2010. Larval sampling. Pp. 55-70 in Dodd, Jr., C. K. (ed.). Amphibian Ecology and conservation, a handbook of techniques. Oxford University Press, Oxford.

SUZUKI, R., SHIMODAIRA H., 2005. Pvclust: hierarchical clustering with P-values. $\mathrm{R}$ package version 1.0-3. Available at: http://www.is.titech.ac.jp/wshimo/prog/pvclust/.

ter BRAAK, C. J. F. \& SMILAUER, P. 1998. CANOCO for Windows, ver. 4.0. Centre for Biometry Wageningen, CPRO-DLO, Wageningen, the Netherlands.

TILMAN, D. 2004. Niche tradeoffs, neutrality, and community structure: A stochastic theory of resource competition, invasion, and community assembly. Proceedings of the national academy of science of USA 101:10854-10861. 
TILMAN, D. \& PACALA, S. W. 1993. The maintance of species richness in plant communities. Pp. 13-25 in Ricklefs, R. E. \& Schulter, D. (eds.). Species diversity in ecological communities. University of chicago press, Chicago.

TOKESHI, M. 1999. Species coexistence, ecological and evolutionary perspectives. Blackwell Science, Oxford. 464 pp.

ULTSCH, G. R., BRADFORD, D.F. \& FREDA, J. 1999. Physiology: copling with the environment. Pp.189-214 in McDiarmid, R. W. \& Altig, R. (eds.). Tadpoles, the biology of anuran larvae. University of Chicago Press, Chicago.

WATKINSON, A. R., GILL, J. A. \& FRECKLETON, R. P. 2003. Macroecology and microecology: linking large-scale patterns of abundance to population processes. Pp. 256-273 in Blackburn, T. M. \& Gaston, K. J. (eds.). Macroecology, concepts and consequences. Blackwell Science, Oxford.

WELLBORN, G. A., SKELLY, D. K. \& WERNER, E. E. 1996. Mechanisms creating community structure across a freshwater habitat gradient. Annual Review of Ecology and Systematics 27:337-363.

WERNER, E. E. \& GLENNEMEIER, K. S. 1999. Influence of forest canopy cover on the breeding pond distributions of several amphibian species. Copeia 1999(1):1-12.

WERNER, E. E., SKELLY, D. K., RELYEA, R. A. \& YUREWICZ, K. L. 2007. Amphibian species richness across environmental gradients. Oikos 116:16971712.

WIEST-JR, J. A. 1982. Anuran succession at temporary ponds in a post Oak-Savanna region of texas. Pp. 39-47 in N. J. Scott, Jr. (ed.). Herpetological Communities. Wildlife Research Report Washington. 
WILBUR, H. M. 1980. Complex life cycles. Annual Review of Ecology and Systematics 11:67-93.

WILBUR, H. M. 1984. Complex life cycles and community organization in amphibians. Pp. 515 in Price, P. W., Slobodchikoff, C. N. \& Gaud, W. S. (eds.). A new ecology, novel approaches to interactive systems. John Wiley \& Sons, New York.

WILBUR, H. M. \& ALFORD, R. A. 1985. Priority effects in experimental pond communities: responses of Hyla to Bufo and Rana. Ecology 66(4):1106-1114.

WOLDA, H. 1987. Seasonality and the community. Pp. 69-95 in Gee, J. H. R. \& Giller, P. S. (eds.). Organization of communities, past and present. Blackwell publishing, Oxford.

YANG, L. H., BASTOW, J. L., SPENCE, K. O. \& WRIGHT, A. N. 2008. What can we learn from resource pulses? Ecology 89(3):621-634. 


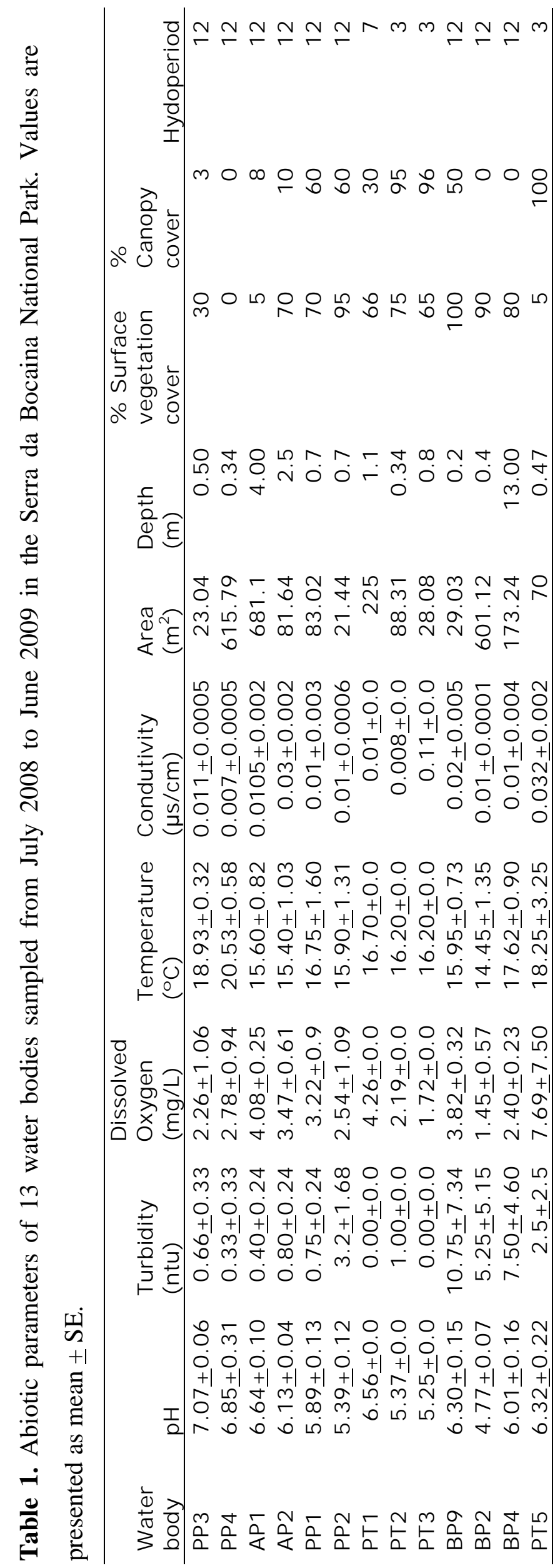



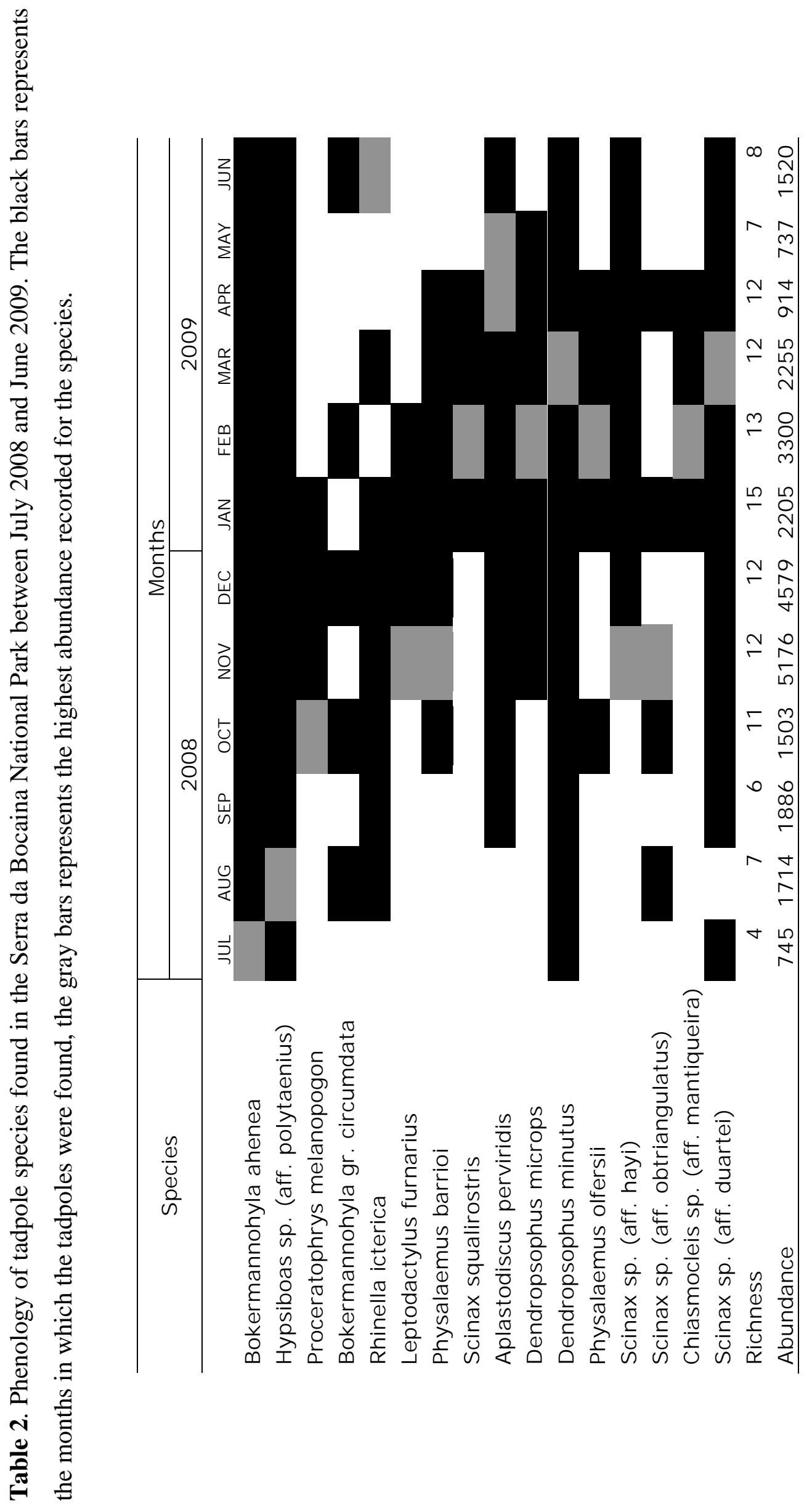


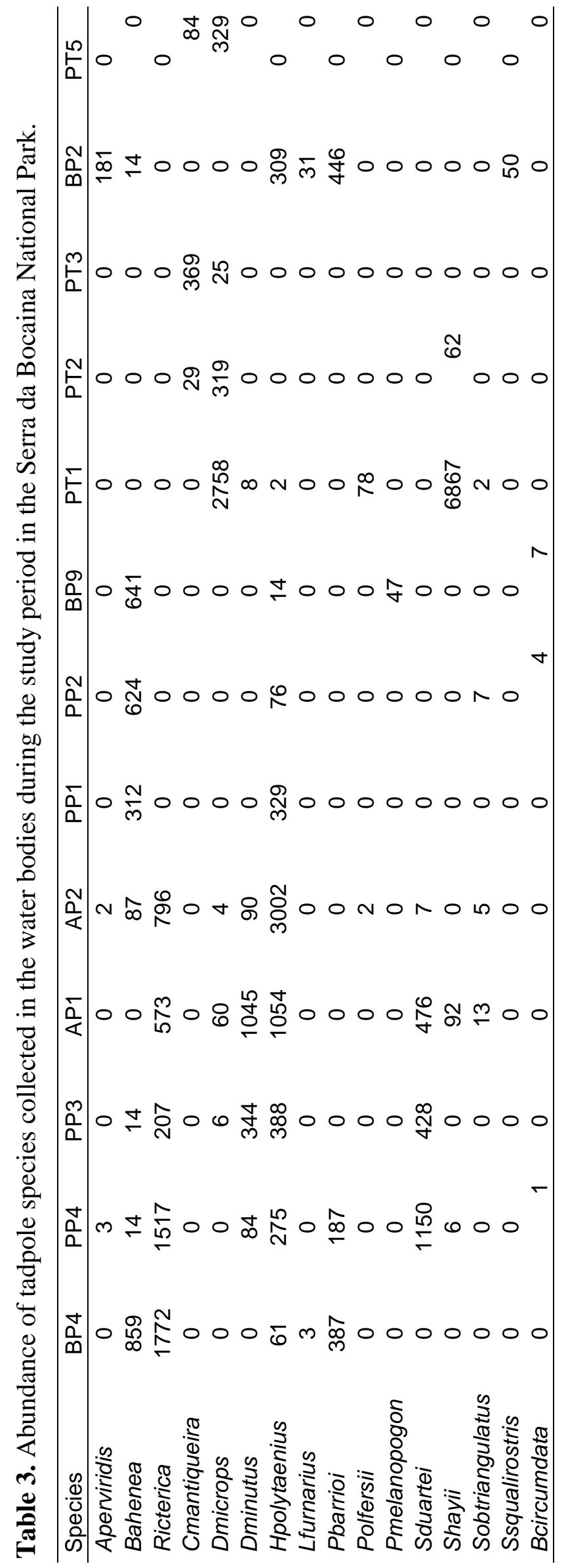




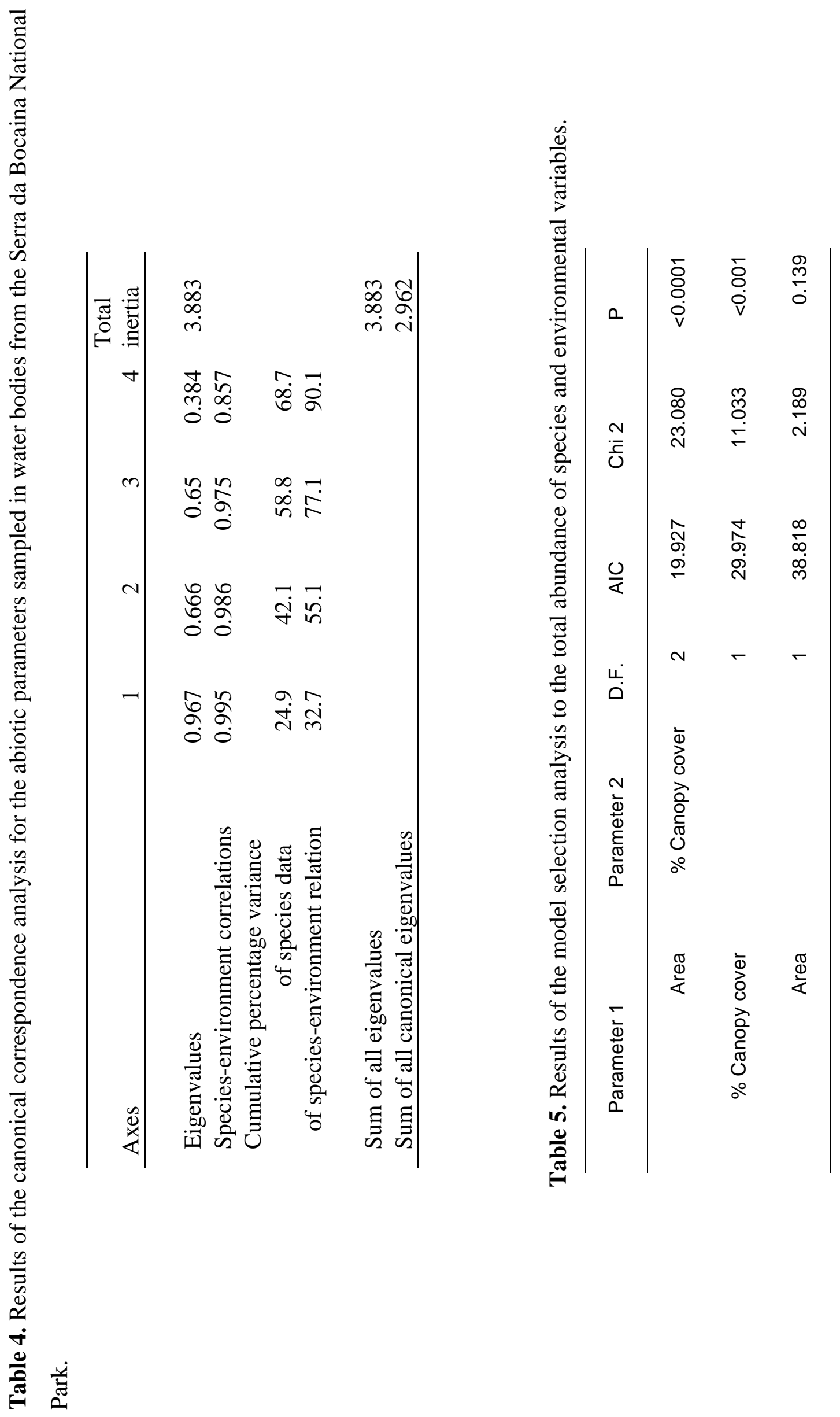




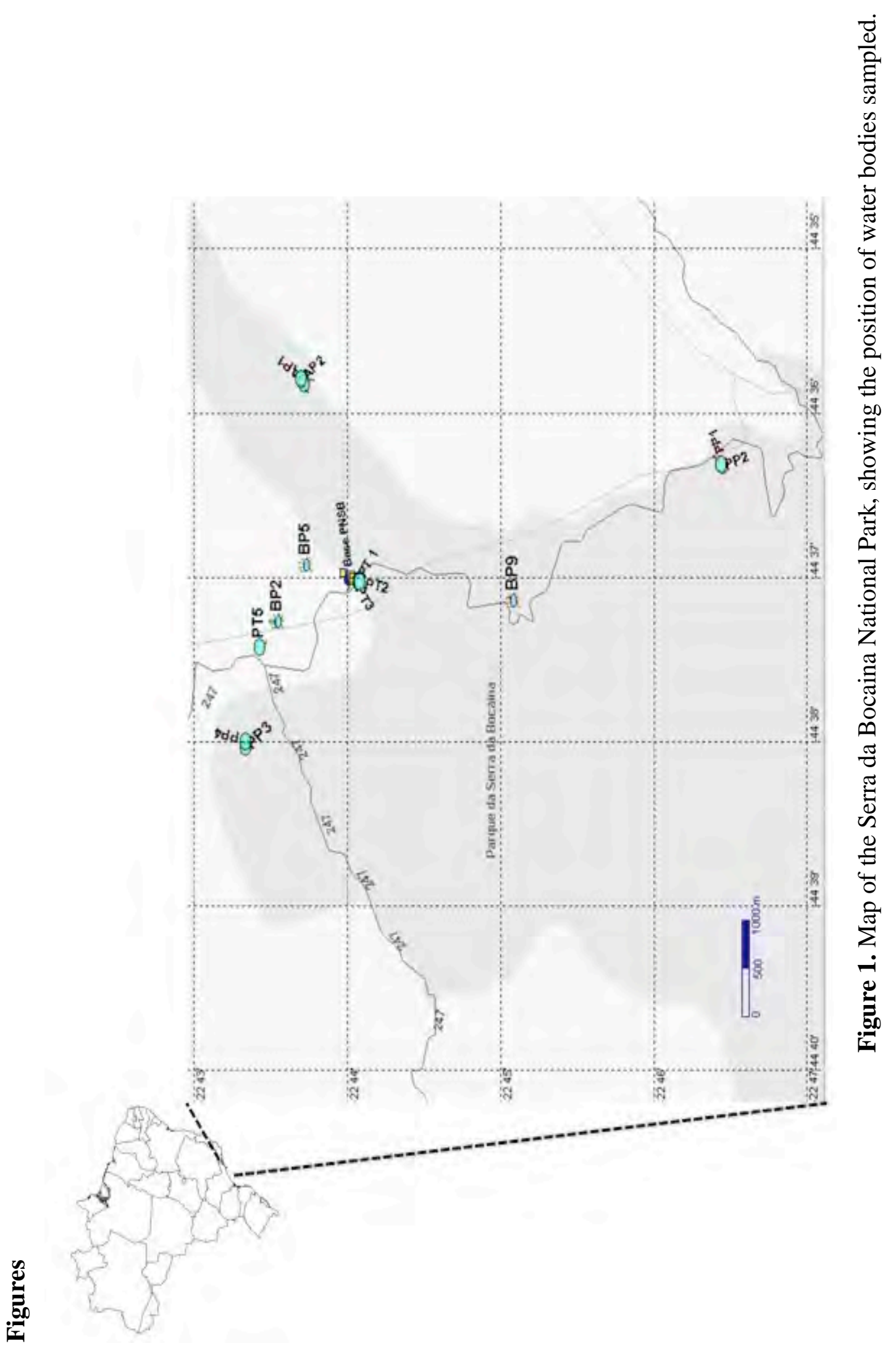




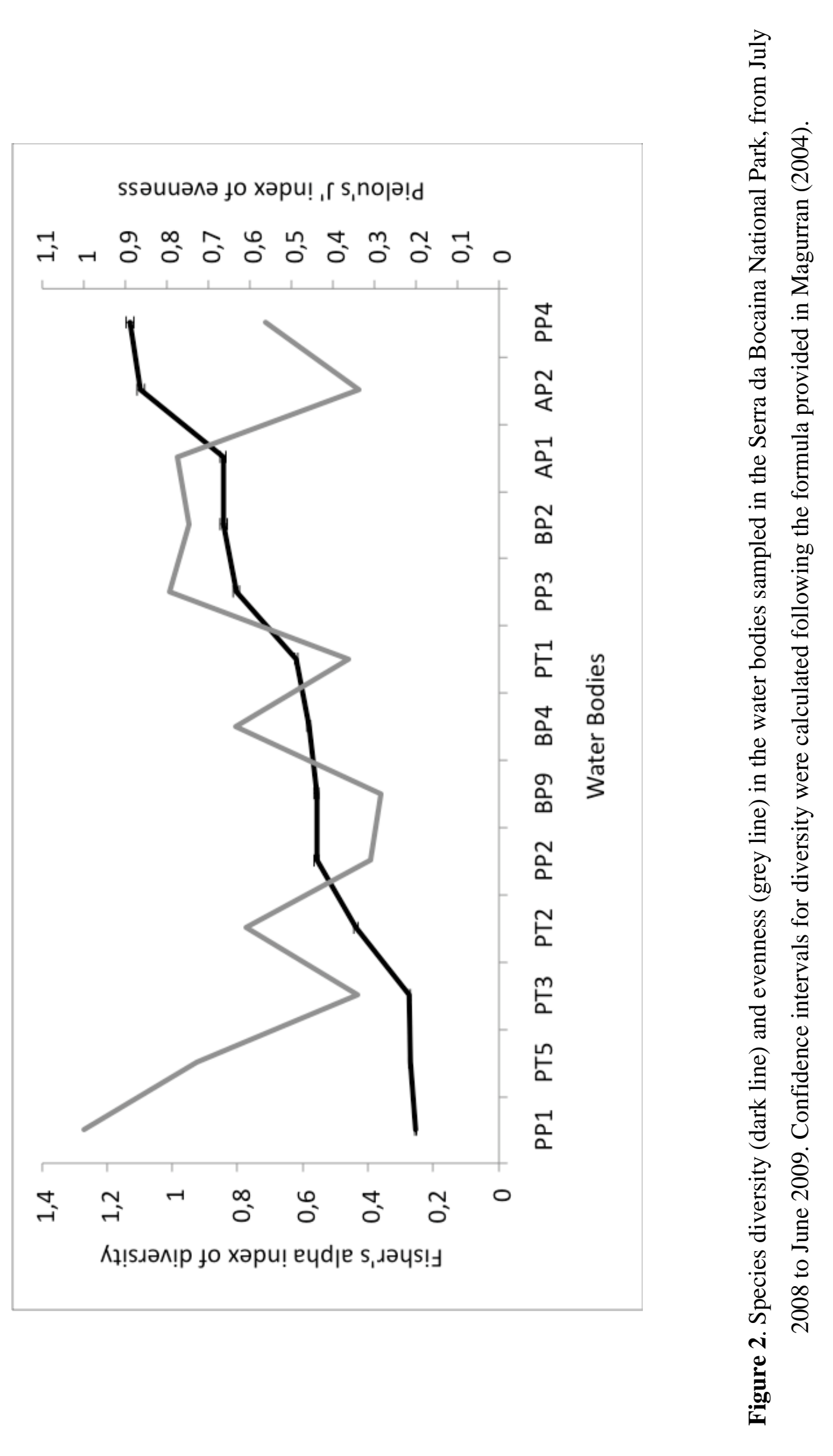




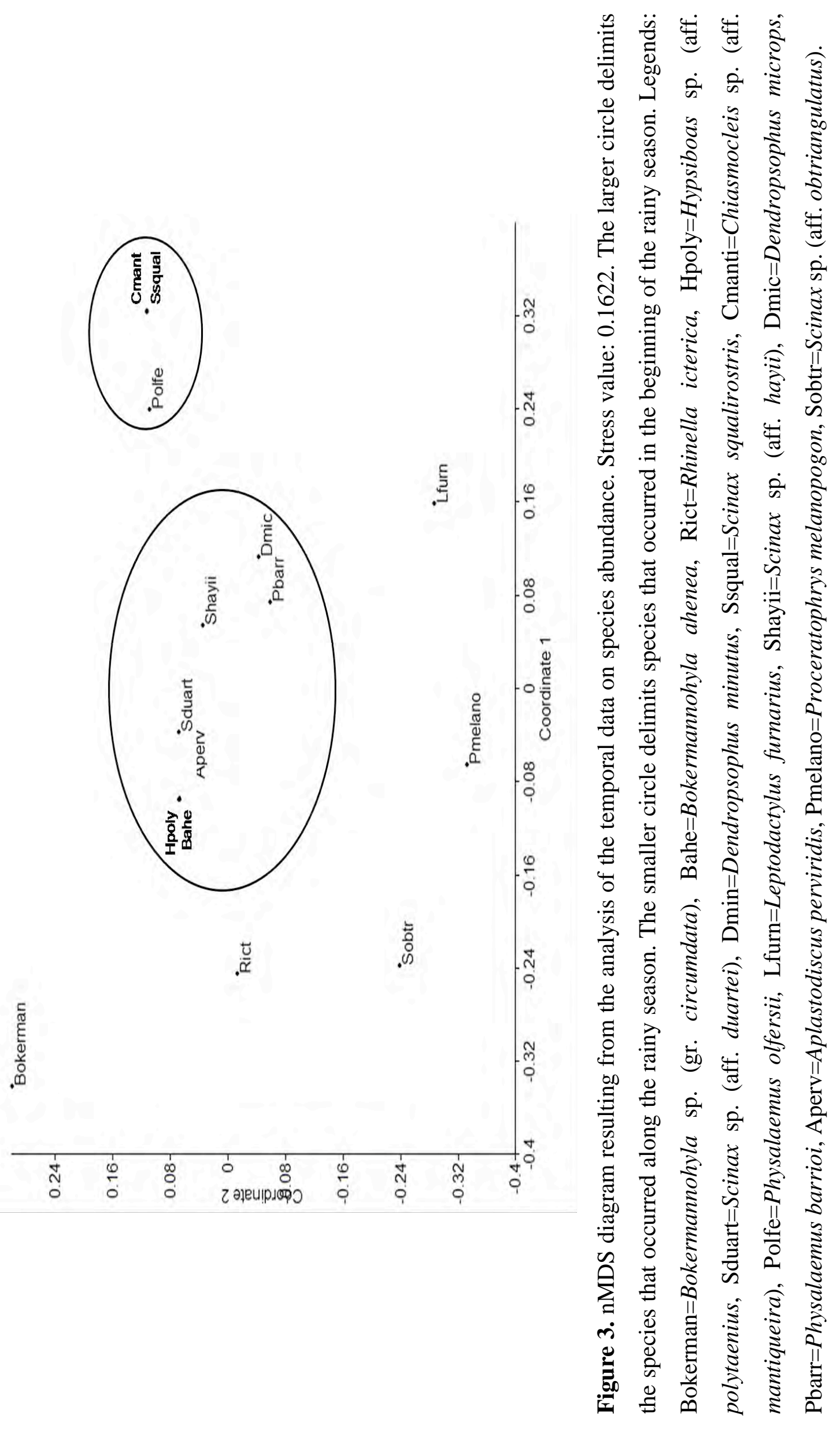




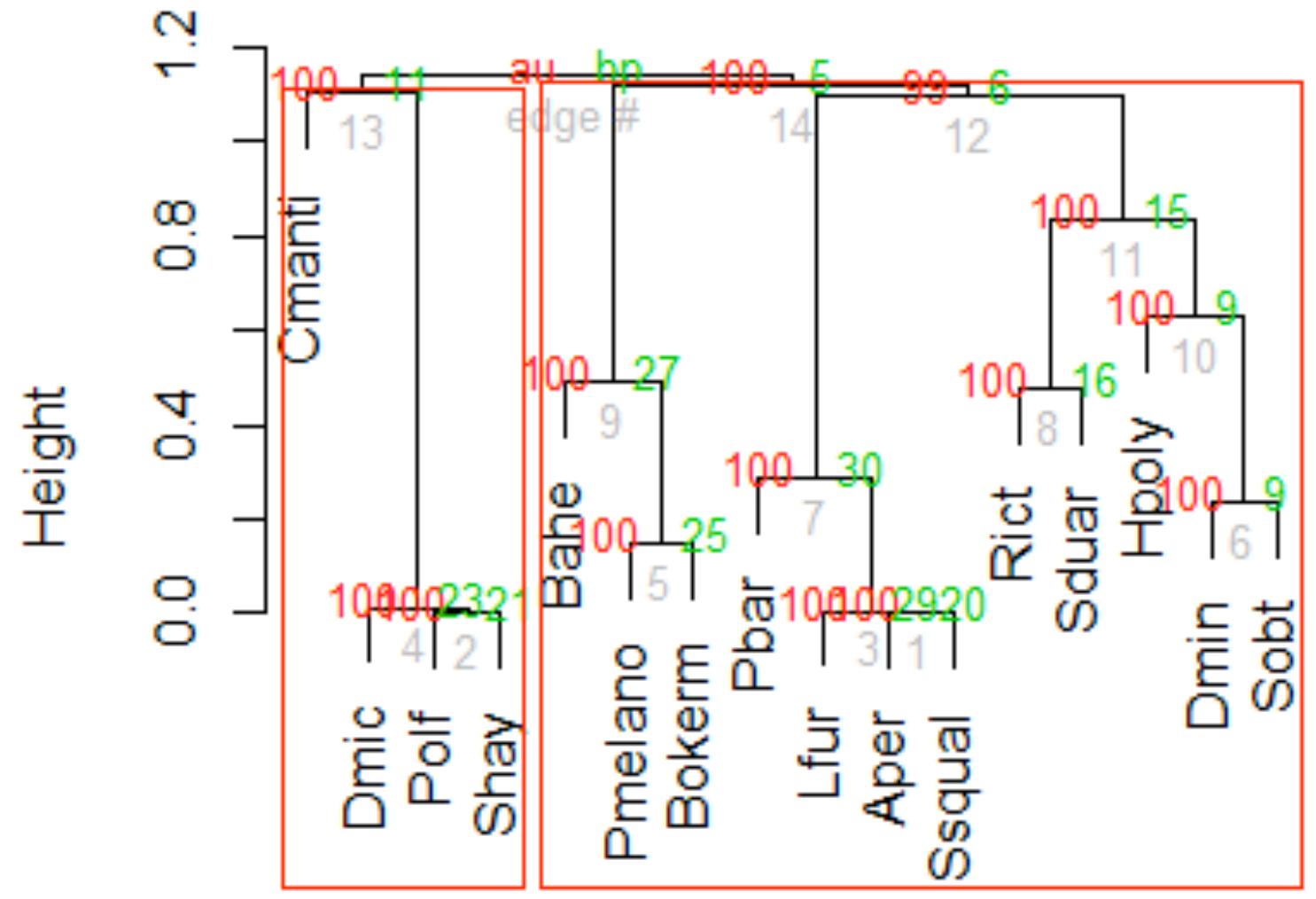

Figure 4. Cluster resulting from the analysis of the spatial data on species abundance. The cluster was built using the UPGMA as a clustering method and correlation as a distance method. The AU stands for Approximate Unbiased p-value and BP stands for Bootstrap. The red squares delimitates the species guilds based on BP and AU values. Cofenetic Correlation Index: 0.9892. The species are labeled as in the former figure 


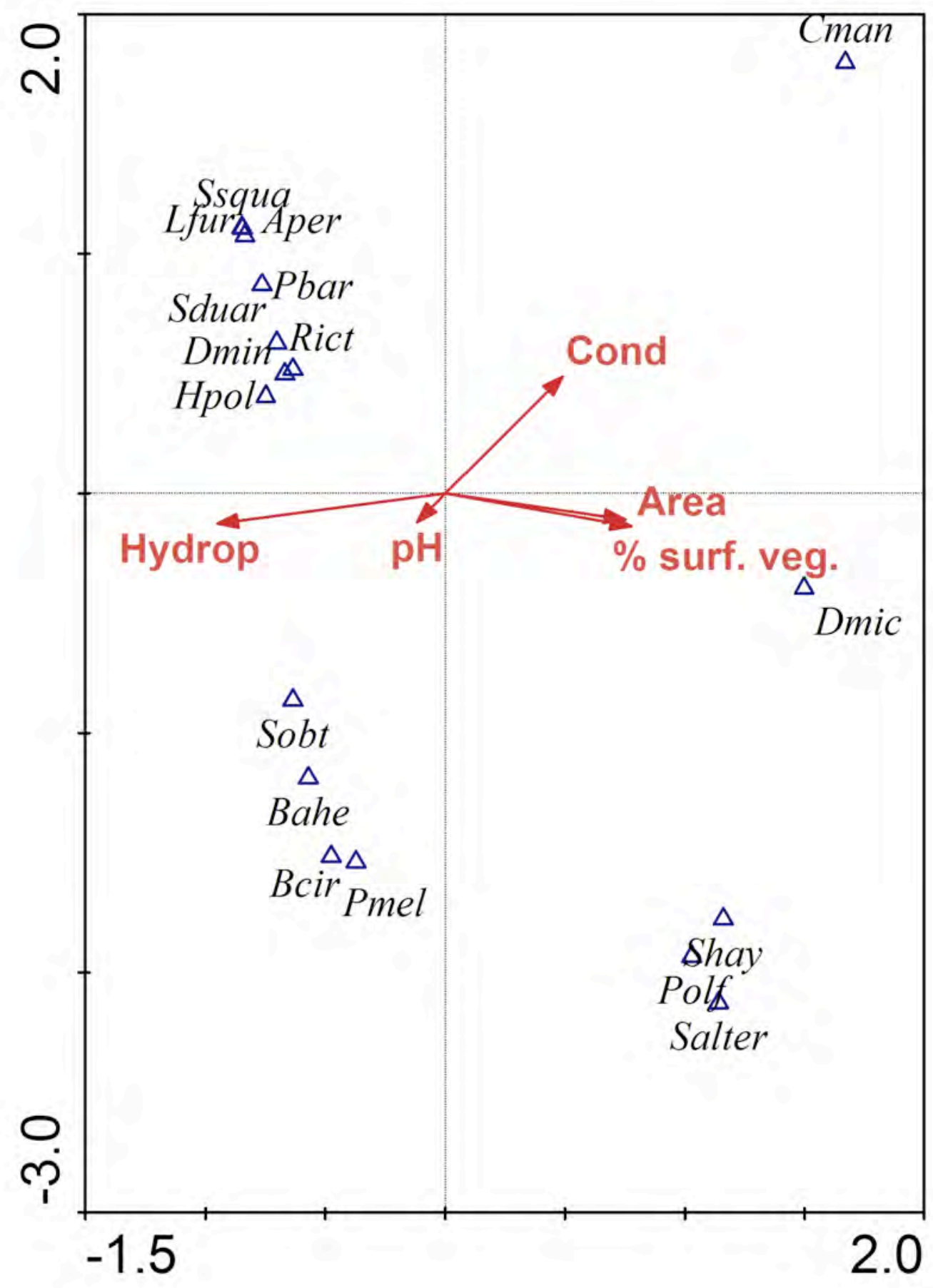

Figure 5. Results of the Canonical Correspondence Analysis. Sspecies are labeled as in figure 1. 


\section{Niche partitioning in an assemblage of pond-dwelling tadpoles}

Diogo Borges Provete ${ }^{1 *}$, Denise Deo Dias ${ }^{1}$, Denise de Cerqueira Rossa-Feres ${ }^{1}$, Itamar Alves Martins ${ }^{2}$

${ }^{1}$ Laboratório de Ecologia Animal, Departamento de Zoologia e Botânica, Instituto de Biociências, Letras e Ciências Exatas (IBILCE), UNESP-Universidade Estadual Paulista, R. Cristóvão Colombo, 2265, 15054-000, São José do Rio Preto-SP, Brasil, dbprovete@gmail.com; denise@ibilce.unesp.br.

${ }^{2}$ Laboratório de Zoologia, Departamento de Biologia, Universidade de Taubaté, Av. Tiradentes, 500, 12030-180, Tabuaté-SP, Brasil, istama@uol.com.br

* Author for correspondence: dbprovete@gmail.com. +55 17 32212366, FAX +55 17 32212736

Running Title: Resource partitioning in tadpole communities

** Manuscrito escrito nas normas do periódico Austral Ecology (ISSN 1442-9985) 


\begin{abstract}
Tadpoles are a conspicuous component of freshwater habitats like ponds, swamps, streams and phytotelmata. However, little is known about its functional role in ecosystems. Resource partitioning studies intent to solve the puzzle of species coexistence by studying the differences in their resource use. Our aim in this study was to identify the main resource axes in which there was higher overlap in resource use by tadpole species by comparison with the resource use pattern in a null community. We collected data on monthly occurrence, pond occupancy and diet items for 11 species of tadpoles in 13 water bodies from Southeastern Brazil, from July 2008 to June 2009. Therefore, representing the three main axes in which animals usually partition the ecological niche. We found that diet was the resource axis in which there was the greater overlap, whereas temporal occurrence and pond occupancy were more partitioned by tadpoles. Physical features of habitats and species-specific physiological constraints can be regarded as responsible for this pattern.
\end{abstract}

Key-Words: diet, tadpoles, hutchinsinoan niche, resource partitioning, Atlantic Rain Forest.

\title{
INTRODUCTION
}

One approach usually used by community ecologists to understand how a multitude of species can coexist in a community is to study the differences in how they use resources. The main assumption of this kind of research programme is that species are competing for limiting resources that are essential for their existence (Schoener 1974, 1986) and that competition is the main force dictating resource use (Gotelli \& Graves 1996). However, this assumption has been replaced a few decades ago, since a variety of processes are being claimed to also produce resource 
partitioning patterns, such as predation and physiological constrainsts, which can frequently act in complex ways (see Werner 1984; Toft 1985). This approach is largely based on the niche theory, and on the idea that species should exhibit tradeoffs (Stearns 1992) in order to coexist locally, i.e., species must exhibit differences in dealing with limiting resources, so organisms that perform better in consuming one resource, perform worse in others, due to morphological, physiological or behavioral constraints (Chase \& Leibold 2003).

Niche theory as applied to such studies is related to resource utilization distribution (Schoener 1989, Chase \& Leibold 2003) and the theory of limiting similarity championed by MacArthur \& Levins (1967). The niche in this way can be defined for a particular species population and gives the functional use of resources arranged along niche axes. As such, it can be represented as the frequency histogram of resource use. This theoretical framework led ecologists to make niche measurements, like niche breadth, niche overlap, and niche partitioning (Chase \& Leibold 2003).

Three resource dimensions have been suggested as the most important in explaining species coexistence: habitat, time and food (see also Pianka 1973, Shoener 1974). It has been proposed that species coexistence in ecological communities is determined by one or two important niche axes (Chase \& Leibold 2003) and in order to coexist, species should diverge in at least one of these niche axis (Shoener 1974). The phenomenon producing this divergence is called, generally, stabilizing mechanisms (sensu Chesson 2000). Schoener (1974), reviewing resource partitioning in ecological communities, found temporal partitioning to be significantly less common than habitat or food type partitioning, mainly due to physiological constraints of species. Toft (1985), mostly based on the findings of Heyer (1974), 
pointed out that amphibian larvae represent a noteworthy exception to this pattern, because in tadpole communities, seasonal time partitioning seems to be the most important resource dimension over the others.

Macrohabitat partitioning among tadpoles is achieved when different species use different types of habitat. This is mainly determined by adult choice of oviposition site (Resetarits \& Wilbur 1989). Food partitioning seems to be less commom (Heyer 1973), although species differ in their oral aparatus (Altig \& Johnston 1989). Probably food items are difficult to partition directly, since ponddwelling tadpoles feed by filter feeding and scraping food from hard substrates (Hoff et al. 1999). However, morphology of tadpoles (Altig \& McDiarmid 1999) allows them to feed in different positions in the water column, which can serve as a second way to partition food.

Null models have been used to ask which niche overlap pattern would be expected in the absence of competition. If niche overlap really influences resource utilization at the community level, niche overlap in nature should be less than in a “competition-free" community (Gotelli \& Graves 1996). However, we cannot infer any mechanism responsible for producing the found pattern, because, for instance, a high niche overlap may reflect intense competition for shared resources or a surplus of resources and the absence of competition (Gotelli \& Graves 1996, Tokeshi 1999).

Our aim in this study was to determine the main resource axis(es) in which there was higher (or lower) overlap. We recorded monthly occurrence as temporal niche, water bodied as spatial niche, along with diet items. Therefore, representing the three main axes in which tadpoles usually partition the ecological niche (Pianka 1973; Toft 1985). Since anurans are poikilotherms and have narrow termal tolerance, being its activity mostly restricted to the warm and wet months of the year (Duellman \& 
Trueb 1994), we predict that the species will exhibit a high overlap in temporal occurrence and that this resource axis will be the least partitioned axis. Tadpoles have different types of oral apparatus, allowing them to consume a wide variety of food items (Altig \& Johnston 1989), thus we predict that there will be a higher degree of niche overlap within guilds of species that share similar oral apparatus than between species from different guilds (Toft 1985). Anuran species have different habitat requirements, with different species reproducing in different types of water bodies. In our sampling, we included water bodies that were in different points along two important environmental gradients: hydroperiod and canopy cover (Wellborn et al. 1996; Schiesari 2006, respectively). Thus, we predict that this could affect to some extent the spatial niche partitioning among species.

\section{METHODS}

\section{Study site}

This study was carried out in the Serra da Bocaina National Park (PNSB, hereafter) $\left(22^{\circ} 44^{\prime} \mathrm{S} ; 4^{\circ} 37^{\prime} \mathrm{W}\right)$, localized at the boundary between the states of São Paulo and Rio de Janeiro in southeastern Brazil. The PNSB comprises presently an area of 104,000 ha and is regarded as one of the main remants of the Atlantic Rain Forest (sensu Ab'Saber 1977) in southeastern Brazil, bearing protected areas of dense tropical rain forest, highland mixed tropical rain forest and highland grasslands (Eiten 1992). Our sampling was concentrated at the area of the Bocaina highlands (1500 m a.s.1.), in the municipality of São José do Barreiro, state of São Paulo. In this region, the climate according to the Köppen-Geiger classification (Peel et al. 2007), is of the type Cwb (humid subtropical highland), with moderated temperatures, dry winters (between April and September) and warm summers (from October to March). The 
annual rainfall varies between 400 and $2100 \mathrm{~mm}$, with mean annual temperature of $22^{\circ} \mathrm{C}$. The relative humidity does not vary too much, with mean indexes between $77 \%$ and $82 \%$.

\section{Sampling procedures}

We sampled 13 water bodies with different morphologies and hydroperiods. We sampled 13 water bodies with different morphologies and hydroperiods. The water bodies comprised: one temporary pond in woodlands (PT5), two permanent ponds in open areas (PP3 and PP4), two swamps in open areas (BP2 and BP5), four permanents ponds in woodlands (AP1, AP2, PP1, and PP2), three temporary ponds in woodlands (PT1, PT2, and PT3), and one swamp in woodlands (BP9) (veja imagens no Apêndice 1). Each water body was sampled once a month, between July 2008 and June 2009. The tadpoles were sampled using a wired deep net ( $3 \mathrm{~mm}$ of mesh) passed through the entire extent of the margins of water bodies (Shaffer et al. 1994). The tadpoles were fixed in the field with $10 \%$ formalin. The identification followed identification keys and direct comparisons with published descriptions. When the identification was not possible using this means, we reared the tadpoles in aquaria, with comercial fish rations. In addition, adult anurans were acoustically monitored monthly in each water body.

\section{Data collection}

We recorded spatial and temporal occupancy of water bodies, in addition to the diet items consumed by tadpoles. Spatial occupancy of water bodies was measured by recording the type of water bodied in which the tadpoles occurred. Temporal occupancy was measured as the months of the year in which tadpoles occurred in water bodies. 
The diet of tadpoles was analyzed following Rossa-Feres et al. (2004). We took one sample of the first centimeter of the gut of five tadpoles of each species between the stages 35 and 38 (Gosner 1960) occurring within all the water bodies sampled between December 2008 and Janurary 2009, the peak of abundance for the majority of species. This part was removed and its content homogeneized in $160 \mu \mathrm{L}$ of Transeau solution (Bicudo \& Menezes 2006). Later, we took $40 \mu \mathrm{L}$ of this solution to analyze in microscope slides. We made one slide for each tadpole specimen. The diet items were counted and identified by making transects on the microslide, on 200x of magnification. Later, to compose the diet, we summed all the items found in the gut of five tadpoles. The algae were identified to genus level using the dichotomous key of Bicudo \& Menezes (2006). Plant fragments of several sizes were classified as Coarse Particulate Organic Matter (CPOM). Zooplankton members were identified to genus or order. We did not record the amount of detritus. To compose the final diet, we summed the items found in the five tadpoles analyzed.

\section{Statistical analysis}

We analyzed the niche partitioning by applying a null model on the Niche overlap module of EcoSim 7.0 (Gotelli \& Entsminger 2001). Following Albrecht \& Gotelli (2001), we analyzed each niche axis at once: monthly occurrence, water bodies occupancy and diet items. Using this aproach, we could measure in which resource axis there was a higher overlap. Data for monthly temporal occurence were arranged in a way that in a matrix each row corresponded to a species and each column corresponded to a month of the year. The entries in the matrix consisted of the abundance of each species. The spatial occurence was analyzed by building a matrix with species abundance in the rows and the 13 ponds in the columns. The diet was 
analyzed with a matrix consisting in the species and the abundance of food items in the columns.

The niche overlap index used was Czekanowski (also known as the quantitative Sørensen index). This index measures the area of intersection of two histograms of resource utilization. The Czechanowski index is a symmetric index of niche overlap. The index approaches 0 for species that share no resource states and approaches 1 for species pairs that have identical resource utilization distributions. (Gotelli \& Graves 1996). We used the randomization algorithm RA3 for the analysis of diet and spatial niche and RA4 for the temporal niche (Winemuller \& Pinka 1990, Gotelli \& Graves 1996). The RA3 algorithm retains the observed niche breadth of the species, and allows utilization of any of the possible resource states. Thus, by using this algorithm we assume that every species could ocurr in any pond and could eat any food item (Albrecht \& Gotelli 2001). However, as anurans are poikilotherms and present narrow termal tolerance (Duellman \& Trueb 1994), thus to analyze temporal occurrence we used the RA4 algorithm, since this algorithm retains both niche breadth and overlap of the species, and the pattern of zero states (Gotelli \& Entsminger 2001). This procedure tends to produce a higher expected niche overlap, consequently had the greatest chance of revealing significant patterns of reduced niche overlap. We run the analysis with 1,000 randomizations and considered as a significant result a value with $\mathrm{p} \leq 0.05$.

\section{RESULTS}

We recorded tadpoles from 11 species occurring during the study period (Tables 1 and 2). The diet of these tadpoles was composed of 52 items, including planktonic and periphitic microalgae, CPOM, cladocerans, protozoans, fungi, and 
arthropod fragments (Table 3). The items most consumed by tadpoles were diatoms and the algae Gonyaulax; the items least consumed were the algae genera Golenkinia, Phytelios, Pleurotaenium.

The result of the null model analysis for monthly occurrence and pond occupancy showed that niche overlap in these axes was not significant (Figs. 1 and 2). We found an overlap in food significantly higher than expected if tadpoles were not competing (Fig. 3, Table 4).

\section{DISCUSSION}

We found that food was the niche axis in which there was the higher overlap, a result that is in accordance with other reports (e.g., Heyer 1973, 1974; Seale 1980; Toft 1985). In addition, the species were distributed randomly in relation to seasonal occurrence and pond occupancy, as well.

The role of food partitioning in explaining tadpole community structure is not consensual. Heyer (1973) and Lajmanovich (2000) carried out studies in very different systems and both concluded that communities of tadpoles are not primarily regulated by food, being the micro- and macrohabitat, as well as seasonal occurrence, playing a major role in resource partitioning. However, Diaz-Paniagua (1985) and Rossa-Feres et al. (2004) found low overlap in diet composition and claimed that microhabitat use and the position in the water column could influence food intake. The rationale is that different species could have the same diet composition but may have ingested them in different microhabitats, a fact also pointed out by other authors (e.g., Toft 1985; Inger 1986; Hoff et al. 1999). In standing water bodies, such those sampled here, direct food partitioning is hard to achieve (Jenssen 1967; Seale \& Beckvar 1980) and tadpole position in the water column may serve as a secondary 
way to partition food (Toft 1985). Thus, historical factors that influenced species traits (Tokeshi 1999), such as fin height and oral apparatus position, may be responsible for shaping food partitioning among tadpoles.

We only analyzed gut contents of tadpoles in the rainy season, when food resources are more abundant and profitable (Schoener 1986). Furthermore, the food types are the same for a number of species, and it is probable that species all converge upon them (Schoener 1986). This could be the case of species inhabiting temporary ponds, in which there is a rapid flush of primary productivity (Wilbur 1980). Thus, these species could be taking advantage of this resource pulse and actually, food is so abundant that species are not competing for them (see also Schiesari et al. 2009 for the role of invertebrate material in diminishing competition).

Tadpoles have been traditionally seen as unselective herbivores and detritivores (Duellman \& Trueb 1994; Hoff et al. 1999). However, currently there is much debate of what tadpoles really eat and their functional role as consumers in freshwater ecosystems (Petranka \& Kennedy 1999; Altig et al. 2007; Schiesari et al. 2009), and some authors have even doubted that traditional diet studies, such as one carried out here, could be useful for assessing the trophic status of tadpoles. In addition, what is often described as their diet may actually serve as substrate and harvestable carrier for assimilated materials (Altig et al. 2007) and may not being assimilated or contributing to nutrition. In our study, we found that tadpoles ingested a wide variety of items, including animal sources (e.g., arthropod fragments), fungi hyphae and microalgae. Thus, tadpoles, as studied here, should be better classified as omnivorous. Our aim in studying diet composition of tadpoles was to assess the pattern of resource partitioning, so we treated each diet item as resource states and we could not evaluate how these items are being assimilated by tadpoles. 
We found that species were randomly distributed in relation to pond occupancy. The spatial distribution of tadpoles might have been affected by gradients of both pond hydroperiod and canopy cover (Wellborn et al. 1996, Schiesari 2006). It seems that some tadpole species can only occur in a narrow range of ponds varying in these two gradients, thus although available, not all ponds are suitable for every species. This species sorting along the two gradients could allow species to partition spatial niche and decrease spatial overlap (Provete et al. unpubl. ms. - Capítulo 1).

Our results indicate that species was randomy distributed in relation to monthly occurrence. Seasonal occurrence has been thought to be less important in explaining species coexistence among tadpoles (Toft 1985). Anuran tadpoles present different developing patterns and may exploit resources from a pond in different times. However, the general strategy employed is to remain in the pond as short as possible, due to predation risk (Wassersug 1975). Nevertheless, as pointed out by Toft (1985), the resource partitioning pattern in anurans is better understood as an interactive phenomenum in which several factors, including evolutionary and physical ones may be involved. Thus, time partitioning can be a result of evolutionary character displacement, where competitive interactions induce some species to breed in differents times of the year (Roughgarden 1976, Tokeshi 1999) or simply a reflect of physiological constraints, which vary among species.

\section{REFERENCES}

Ab'Saber A. N. (1977) Os domínios morfoclimáticos na América do sul - primeira aproximação. Geomorfologia 52, 1-21.

Albrecht M. \& Gotelli N. J. (2001) Spatial and temporal niche partitioning in grassland ants. Oecologia 126, 134-41. 
Altig R. \& Johnston G. F. (1989) Guilds of anuran larvae: relationships among developmental modes, morphologies, and habitats. Herpetol. Monogr. 3, 81-109.

Altig R. \& McDiarmid R. W. (1999) Diversity: Familial and generic characterizations. In: Tadpoles, the biology of anuran larvae (eds R. W. McDiarmid and R. Altig) pp. 295-337. University of Chicago Press, Chicago.

Altig R., Whiles M. R. \& Taylor C. L. (2007) What do tadpoles really eat? Assessing the trophic status of an understudied and imperiled group of consumers in freshwater habitats. Freshwater Biol. 52, 386-95.

Bicudo C. E. M. \& Menezes M. (2006) Gêneros de algas de águas continentais do Brasil. Rima, São Carlos, Brazil.

Chase J. M. \& Leibold M. A. (2003) Ecological Niches, linking classical and contemporary approaches. Chicago University Press, Chicago.

Chesson P. (2000) Mechanisms of maintenance of species diversity. Annu. Rev. Ecol. Syst. 31, 343-66.

Diaz-Paniagua, C. (1985) Larval diets related to morphological characters of five anuran species in the Biological Reserve of Doñana (Huelva, Spain). AmphibiaReptilia 6, 307-322.

Duellman W. E. \& Trueb L. (1994) Biology of amphibians. Johns Hopkins University Press, Baltimore.

Eiten G. (1992) Natural Brazilian vegetation types and their causes. An. Acad. Bras. Ciênc. 64, 35-65.

Gosner K. L. (1960) A simplified table for staging anuran embryos and larvae with notes on identification. Herpetologica 16, 183-90.

Gotelli N. J. \& Graves G. R. (1996) Null models in ecology. Smithsonian Institution Press, Washington.

Gotelli N.J. \& Entsminger G.L. (2001) EcoSim: Null models software for ecology. Version 7. Acquired Intelligence Inc. \& Kesey-Bear. Jericho. http://garyentsminger.com/ecosim.htm. Last accessed 3 Dec 2009.

Heyer W. R. (1973) Ecological interactions of frog larvae at a seasonal tropical location in Thailand. J. Herpetol 7, 337-61.

Heyer W. R. (1974) Niche measurements of frog larvae from a seasonal tropical location in Thailand. Ecology 55, 651-6. 
Hoff K., Blaustein A. R., McDiarmid R. W. \& Altig R. (1999) Behavior: interactions and their consequences. In: Tadpoles. The biology of anuran larvae (eds R. W. McDiarmid and R. Altig) p. 458. University of Chicago Press, Chicago.

Inger R. F. (1986) Diets of tadpoles living in a Bornean rain forest. Alytes 5, 153-64.

Jenssen T. A. (1967) Food habits of the green frog, Rana clamitans, before and during metamorphosis. Copeia 1967, 214-8.

Lajmanovich R. C. (2000) Interpretación ecológica de una comunidad larvaria de anfíbios anuros. Interciência 25, 71-9.

Leibold M. A. (1995) The niche concept revisited: mechanistic models and community context. Ecology 76, 1371-82.

Macarthur R. \& Levins R. (1967) The Limiting Similarity, Convergence, and Divergence of Coexisting Species. Am. Nat. 101, 377-85.

Peel M. C., Finlayson B. L. \& McMahon T. A. (2007) Updated world map of the Köppen-Geiger climate classification. Hydrol. Earth Syst. Sc. 11, 1633-44.

Petranka J. W. \& Kennedy C. A. (1999) Pond tadpoles with generalized morphology: is it time to reconsider their functional roles in aquatic communities? Oecologia 120, 621-31.

Pianka E. R. (1973) The structure of lizard communities. Annu. Rev. Ecol. Syst. 4, 53 74.

Resetarits W. J. \& Wilbur H. M. (1989) Choice of oviposition site by Hyla chrisoscelis: role of predators and competitors. Ecology 70, 220-8.

Rossa-Feres D. C., Jim J. \& Fonseca M. G. (2004) Diets of tadpoles from a temporary pond in southeastern Brazil (Amphibia, Anura). Rev. Bras. Zool. 21, 745-54.

Roughgarden J. (1976) Resource partitioning among competing species - a coevolutionary approach. Theor. pop. biol. 9, 388-424.

Schiesari L. (2006) Pond canopy cover: a resource gradient for anuran larvae. Freshwater Biol. 51, 412-23.

Schiesari L., Werner E. E. \& Kling G. W. (2009) Carnivory and resource-based niche differentiation in anuran larvae: implications for food web and experimental ecology. Freshwater Biol. 54, 572-86.

Schoener T. W. (1974) Resource partitioning in ecological communities. Science 185, 27-39. 
Schoener T. W. (1986) Resource partitioning. In: Community ecology, pattern and process (ed J. Kikkawa and D. J. Anderson) p. 91-126. Blackwell Scientific Publications, Oxford.

Schoener T. W. (1989) Ecological niche. In: Ecological concepts (ed J. M. Cherret) p. 385. Blackwell Scientific, Oxford.

Seale D. B. (1980) Influence of amphibian larvae on primary production, nutrient flux, and competiton in a pond ecosystem. Ecology 61, 1531-50.

Seale D. B. \& Beckvar N. (1980) The comparative ability of anuran larvae (genera: Hyla, Bufo and Rana) to ingest suspended blue-green algae. Copeia 1980, 495503.

Shaffer H. B., Alford R. A., Woodward B. D., Richards S. J., Altig R. \& Gascon C. (1994) Quantitative sampling of amphibian larvae. In: Measuring and monitoring biological diversity - Standard methods for amphibians (eds W. R. Heyer, M. A. Donnelly, R. W. McDiarmid, L.-A. C. Hayek and M. Foster) pp. 130-40. Smithsonian institution press, Washington.

Stearns, S.C. (1992) The evolution of life histories. Oxford University Press, Oxford.

Tokeshi M. (1999) Species coexistence, ecological and evolutionary perspectives. Blackwell Science, Oxford.

Toft C. A. (1985) Resource partitioning in amphibians and reptilies. Copeia 1985, 121.

Wassersug R. J. (1975) The adaptive significance of the tadpole stage with comments on the maintenance of complex life cycles in anurans. Am. Zool. 15, 405-17.

Wellborn G. A., Skelly D. K. \& Werner E. E. (1996) Mechanisms creating community structure across a freshwater habitat gradient. Annu. Rev. Ecol. Syst. 27, 337-63.

Werner E. E. (1984) The mechanisms of species interactions and the organization in fishes. In: Ecological communities, conceptual issues and the evidence (eds D. R. Strong, D. Simberloff, L. G. Abele and A. B. Thistle) pp. 360-82. Princeton University Press, Pronceton.

Wilbur H. M. (1980) Complex Life Cycles. Annu. Rev. Ecol. Syst. 11, 67-93.

Winemiller K. O. \& Pianka E. R. (1990) Organization in natural assemblages of desert lizards and tropical fishes. Ecol. monogr. 60, 27-55. 


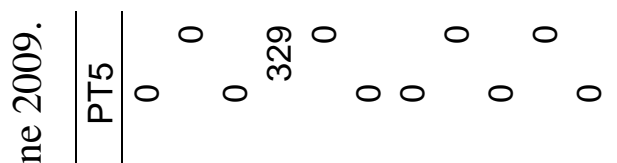

命

ల్ర

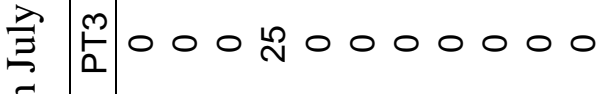

㢣

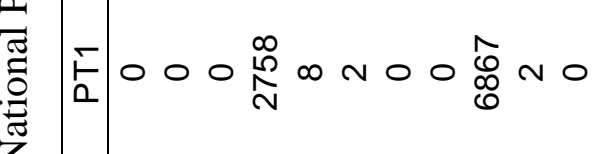

营

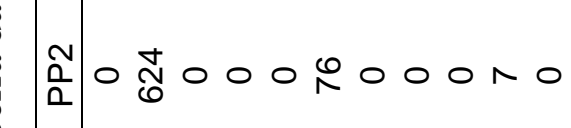

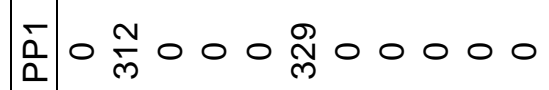

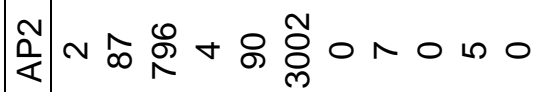

产

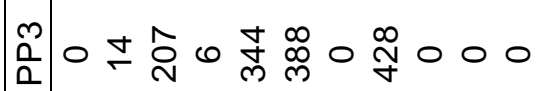

s

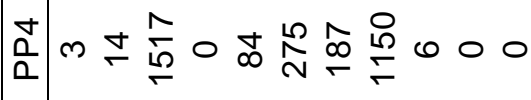

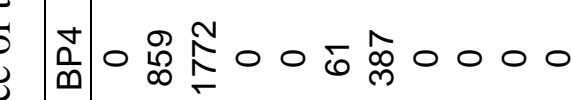




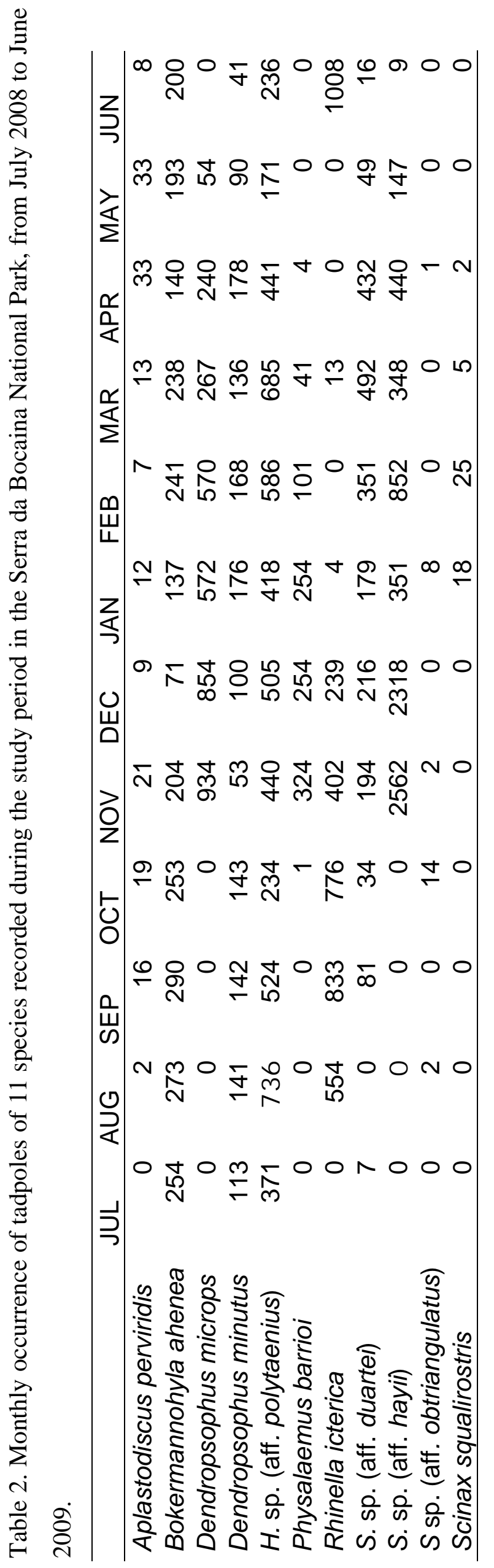




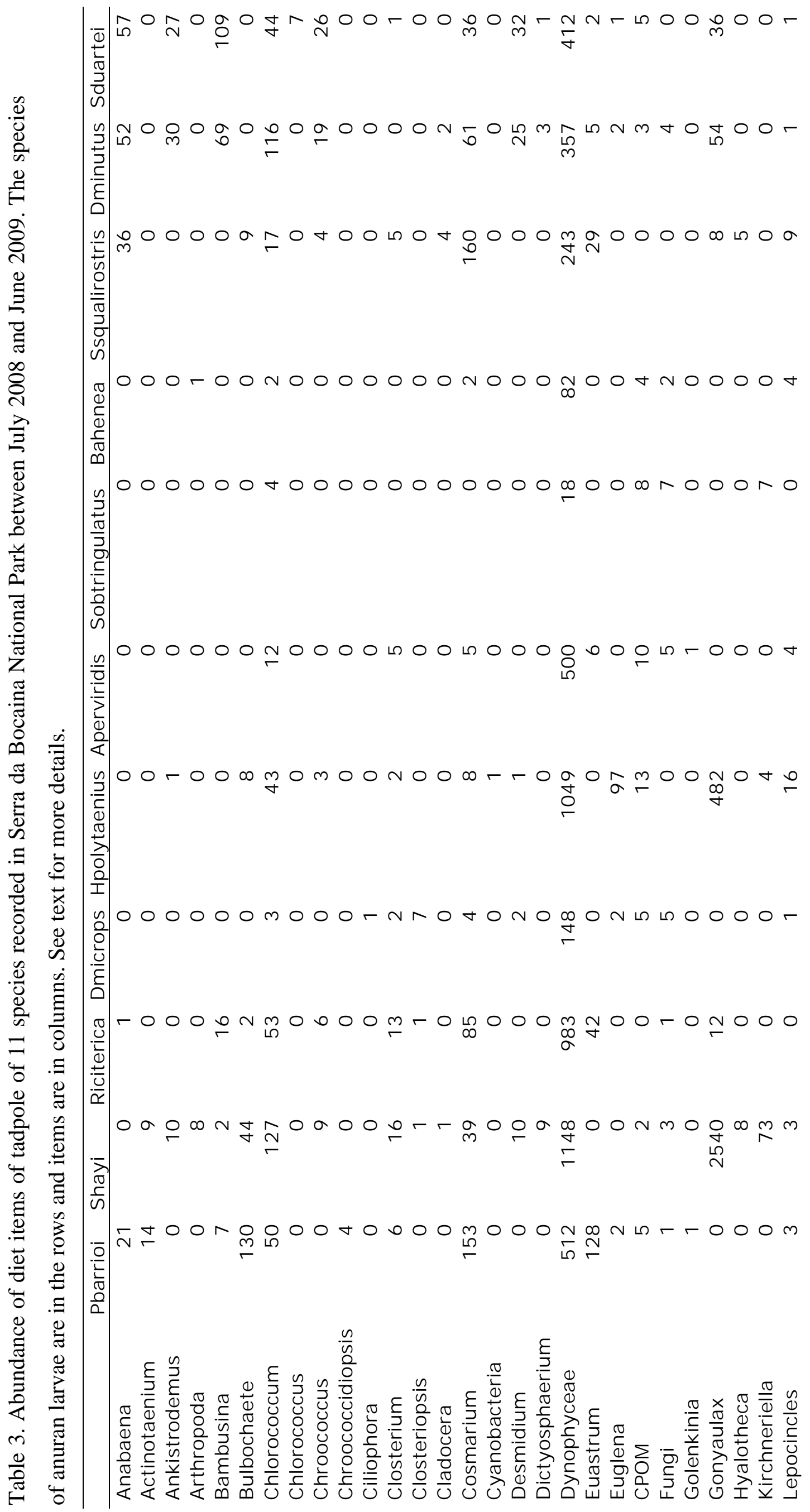




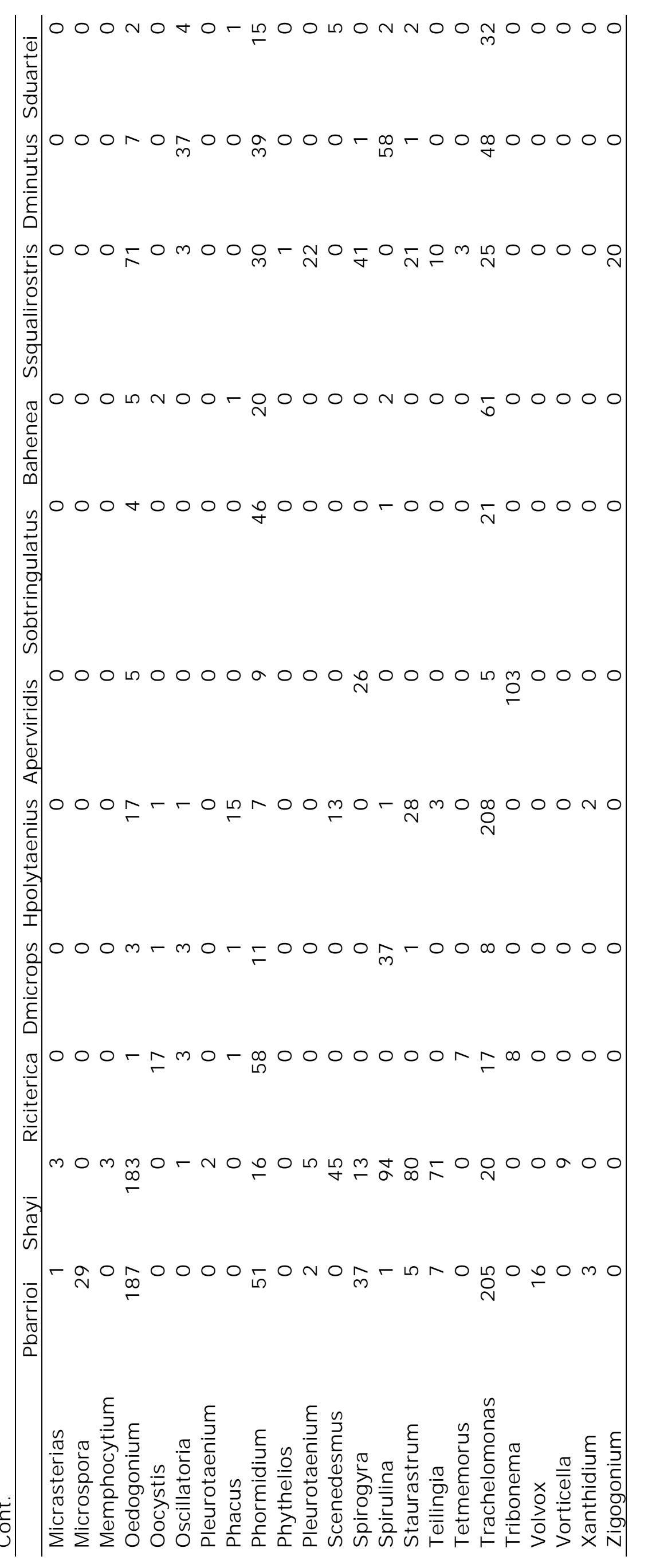




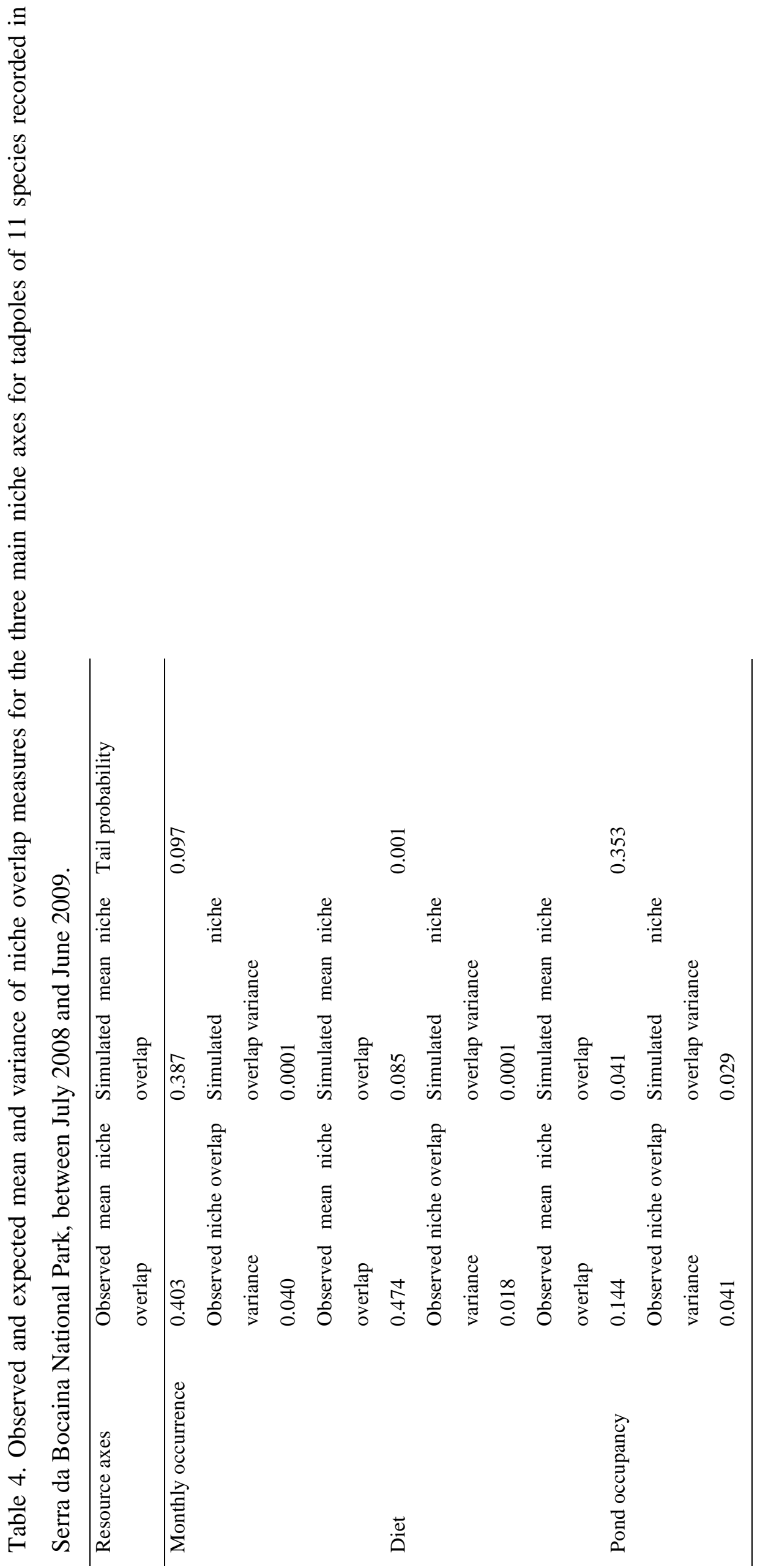




\section{Figures}

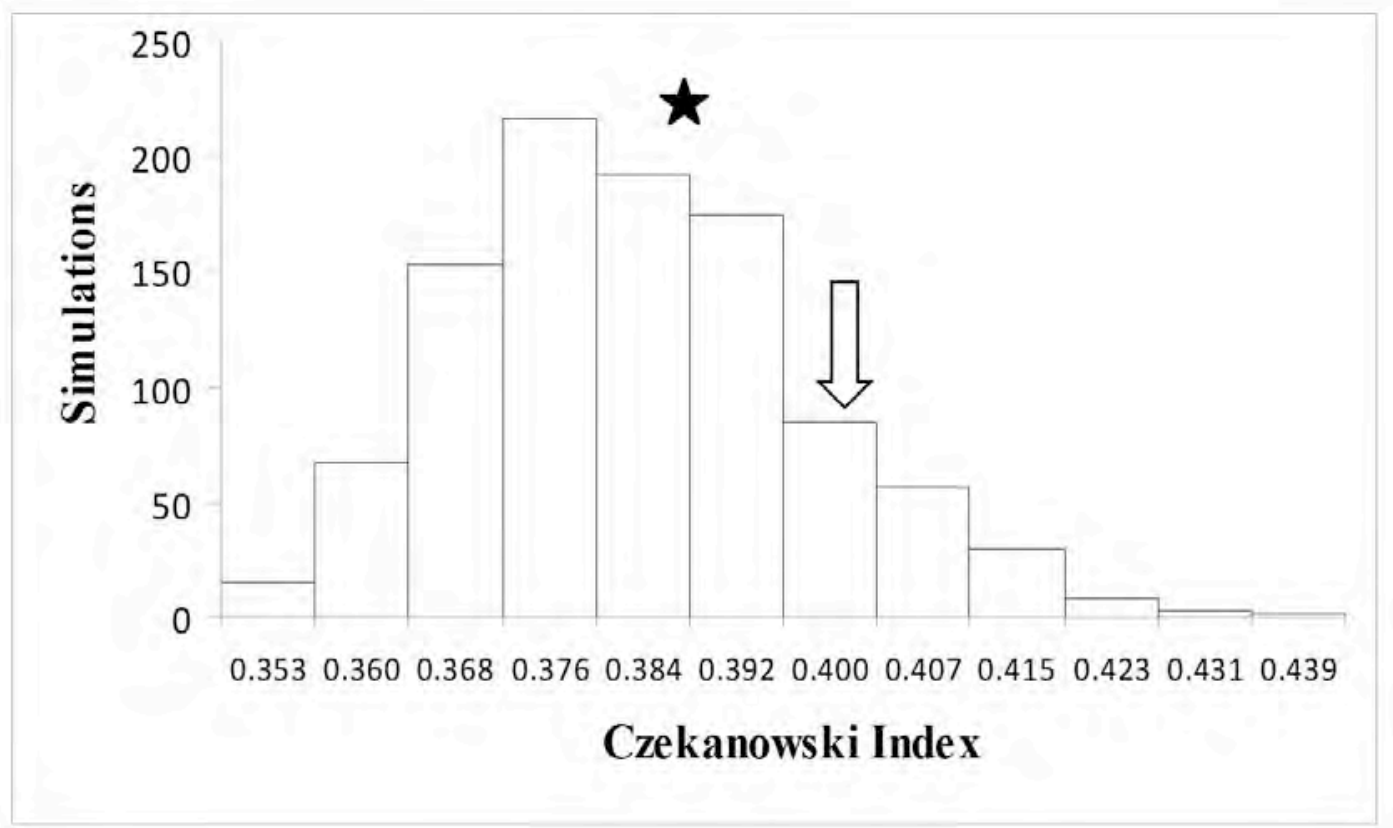

Figure 1. Frequency distribution of the simulated values of niche overlap for monthly occurrence of tadpoles of 11 species recorded in Serra da Bocaina National Park, between July 2008 and June 2009. The arrow represents the observed niche overlap. The star represents the simulated niche overlap.

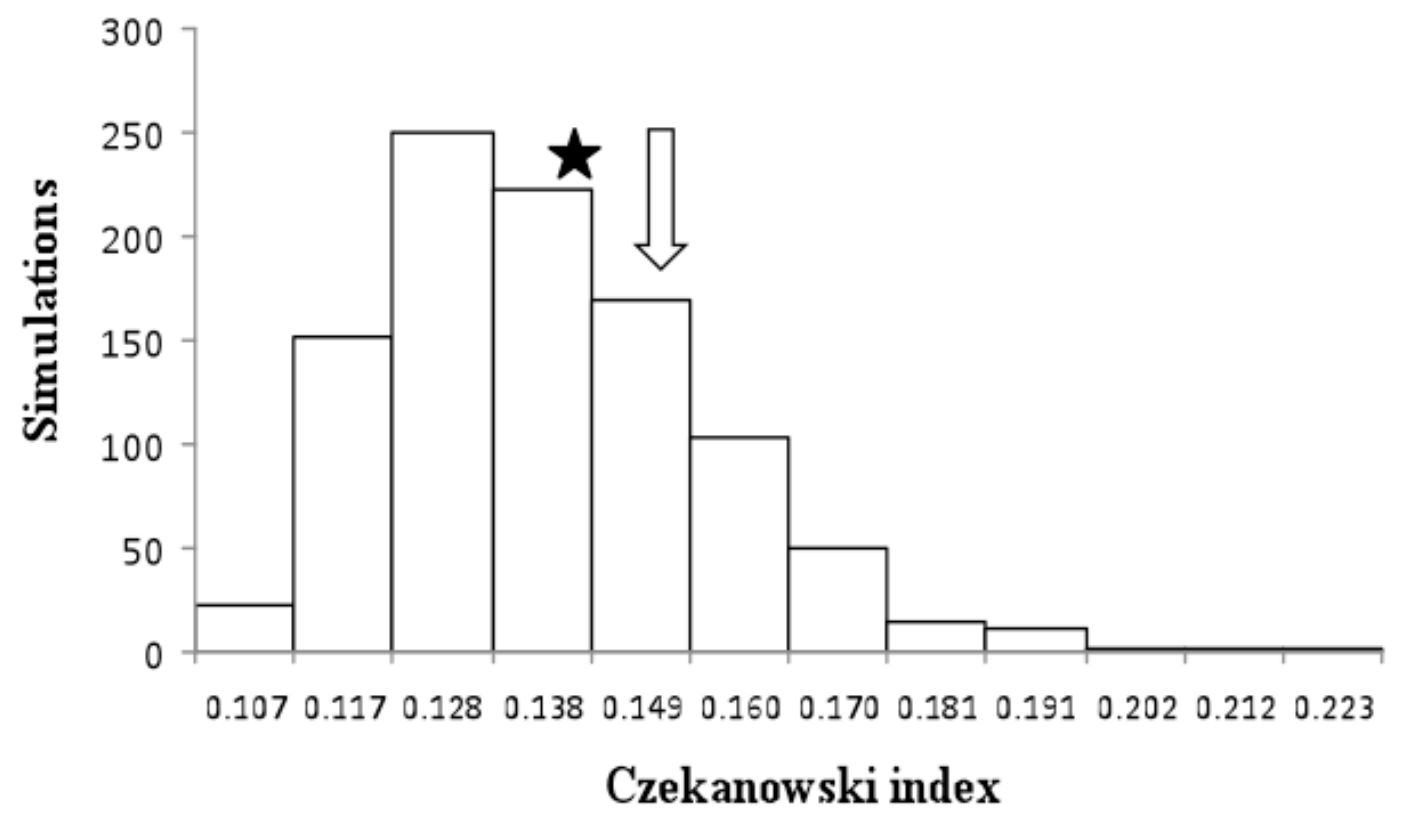

Figure 2. Frequency distribution of the simulated values of niche overlap for pond occupancy of tadpoles of 11 species recorded in Serra da Bocaina National Park, 
between July 2008 and June 2009. The arrow represents the observed niche overlap. The star represents the simulated niche overlap.

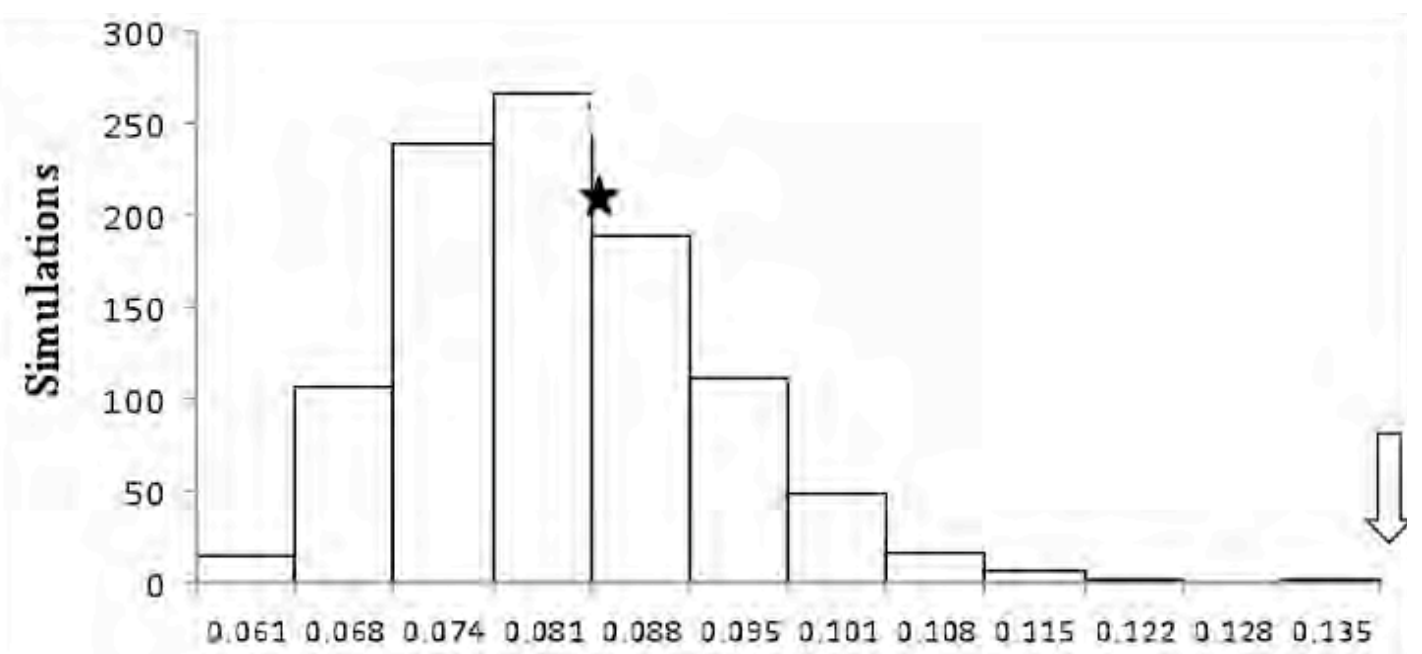

Czekanowski index

Figure 3. Frequency distribution of the simulated values of niche overlap for diet of tadpoles of 11 species recorded in Serra da Bocaina National Park, between July 2008 and June 2009. The arrow represents the observed niche overlap. The star represents the simulated niche overlap. 
Co-occurrence patterns between tadpoles and predaceous insects in ponds: an approach using null models

Diogo Borges Provete ${ }^{\mathrm{a}^{*}}$, Thiago Gonçalves-Souza ${ }^{\mathrm{b}}$, Denise de Cerqueira RossaFeres $^{\mathrm{a}}$, Itamar Alves Martins ${ }^{\mathrm{c}}$

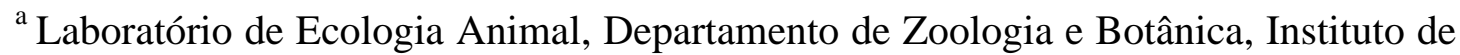
Biociências, Letras e Ciências Exatas (IBILCE), UNESP-Universidade Estadual Paulista, R. Cristóvão Colombo, 2265, 15054-000, São José do Rio Preto-SP, Brasil, dbprovete@gmail.com; denise@ibilce.unesp.br.

${ }^{\mathrm{b}}$ Departamento de Zoologia e Botânica, Instituto de Biociências, Letras e Ciências Exatas (IBILCE), UNESP-Universidade Estadual Paulista, R. Cristóvão Colombo, 2265, 15054-000, São José do Rio Preto-SP, Brasil, tgoncalves.souza@gmail.com.

${ }^{\mathrm{c}}$ Laboratório de Zoologia, Departamento de Biologia, Universidade de Taubaté, Av. Tiradentes, 500, 12030-180, Tabuaté-SP, Brasil, istama@uol.com.br

*Author for correspondence: dbprovete@gmail.com.

** Artigo escrito nas normas do periódico Acta Oecologica (ISSN 1146-609X) 


\begin{abstract}
Predation is an important mechanism shaping ecological communities. Predators can influence spatial distribution of its prey, and the first step to understand how they affect prey communities is to study the joint habitat selection by both predators and prey. However, many studies concerning this issue are theoretical approaches and, until this moment, just a few empirical studies tested how predators and prey are spatially distributed. In this study, we address this question using anuran tadpoles and predaceous aquatic insects as model organisms. We employed null models to investigate the co-occurrence between each tadpole species and predaceous insects in a pair-wise fashion. We found that the majority of associations between tadpoles and insects was random (96.3\%), whereas $2.6 \%$ were negative and $1.1 \%$ was positive. These results suggest that predaceous aquatic insects do not influence the habitat use by anuran tadpoles in the studied spatial scale. Thus, physical features of habitats may have a grater importance in habitat selection by tadpoles than the presence of invertebrate predadors.
\end{abstract}

Key-words: game theory, null models, tadpoles, community structure, predator-prey interactions, habitat selection, Brazilian Atlantic Rain Forest.

\title{
1. Introduction
}

Predation has been regarded as one of the main processes that can influence prey population dynamics (Sih, 1987; Wilbur, 1988) and community structure (Connell, 1975; Sih et al., 1985). The effects of predation in prey communities include behavioral modification (Werner and Anholt, 1996), differential use of microhabitats (Werner and Gilliam, 1984), prey richness change (Paine, 1966), limitation of spatial distribution (Skelly, 1995), and abundance reduction (Morin, 
1983). In anuran amphibians, predation has been thought to be a key factor regulating tadpole mortality (Alford, 1999). In addition, adult females generaly avoid laying eggs in sites with high predation risk (Resetarits and Wilbur, 1989; Crump, 1991; Hopey and Petranka, 1995). Therefore, predation can alter the spatial distribution and relative abundance of anuran species (Relyea, 2001), being considered as the main factor regulating species composition and richness (Heyer et al., 1975; Morin, 1983; Gascon, 1995; Alford, 1999). For instance, Eterovick and Barata (2006), found a negative relationship between tadpole species richness and abundance of predaceous invertebrates (Belostomatidae and Odonata) in streams in southeastern Brazil. Other studies in the Amazon showed that predation by fishes were the main factor influencing species composition in tadpole communities (Gascon, 1992; AzevedoRamos et al., 1999).

The spatial distribution of predators and prey has important consequences in population and community level (Hammond et al., 2007). The distribution pattern influences the encounter rates between predators and their preys, predation rates, and the population dynamics of both predators and preys (Sih, 2005). However, both theoretic and empirical studies generaly consider only one component of this system at once, fixing the other in space; the result is a lack of studies involving the habitat choice by both predators and prey when these are free to move among habitat patches (Lima, 2002). In general, prey tends to avoid areas with high predation risk, whereas predators select areas with high prey density (reviewed in Lima and Dill, 1990).

Among theories that predict prey and predator habitat use, game theory (Maynard Smith, 1982) has received great attention in the last years (e.g., Sih, 1984, 1998, 2005; Hugie and Dill, 1994; Hammond et al., 2007; Dupuch et al., 2009). One of the premises of this theory is that predators and prey demonstrate adaptative 
responses to each other (Sih, 1998). In this context, to choose a habitat both predators and prey should evaluate the availability of food resources, competition levels, and the predation risk among habitat patches (Sih, 1998). Generally, habitat choice by predators depends on the habitat use by prey (Hugie and Dill, 1994). As a particular model of game theory, the ideal free distribution hypothesis (Fretwell and Lucas, 1970) predicts that predators tend to aggregate in patches rich in resources used by its prey. On the other hand, prey tends to aggregate in "safe" patches, even if these sites are resource poor (Hugie and Dill, 1994; Hamilton et al., 2007).

The effects of predators on the spatial distribution of tadpoles was extensively evaluated at small scale or in laboratory experiments to investigate the behavioral, morphological, or ontogenetic responses of tadpoles to several "gape-limited" predators (reviewed in Alford, 1999). In general, the results of these studies are extrapolated to multi-species communities. However, this approach could hide a wide sort of interactions that occurr in large scale. For instance, Lima (2002), point out that large scale behavioral phenomena (e.g., habitat choice) are virtually unexplored, and thus need more empirical attention. These large scale studies discuss the question if prey have "large scale" information about the behavior of predators and other prey, or if simply the phenomena observed in large scale are the result of decisions made at "small scale" (Lima, 2002).

Null models have been widely used to investigate patterns in species distribution and to identify possible mechanisms (e.g., competition, mutualism, mutual antagonism) or assembly rules in ecological communities (Gotelli and Graves, 1996). A null model generates several communities that exist in the absence of any particular mechanism and compare it with patterns in real communities. Specifically to test hypothesis about species co-occurrence, these models quantify the number of 
distributions in which species never co-occur (checkerboard distributions) and those in which the species always co-occur (permissible distributions) comparing it with random distributions (Gotelli and Graves, 1996). However, the rejection of a null model does not provide evidences to relate an ecological process to a pattern found (Peres-Neto et al., 2001), since different processes can generate similar patterns (Gotelli and Graves, 1996).

The null models that are frequently used take into account the total sum of rows and columns as a constraint mechanism. However, the use of metrics based on sums over all species to locate unusual co-occurrence patterns may obscure pair-wise co-occurrence patterns (Harvey et al., 1983; Sanderson, 2004). A metric, that compares species pairs whose distributions are derived from a null model that considers all species and sites equally using constraints consistent with the observed community, is more useful in an ecological context because it considers pairwise cooccurrences directly and is not confounded by summing over all community members (Sanderson, 2004).

We focused on two mutually exclusive hypotheses about the spatial distribution of predaceous insects and tadpoles: (i) from the point of view of natural history of prey (tadpoles), we expect that tadpoles exhibit a negative co-occurrence pattern with predaceous insects (checkerboard distribution), since habitat use by tadpoles is determined by adults, which could evaluate the predation risk before laying eggs on a site (Resetarits and Wilbur, 1989); (ii) on the other hand, according to predictions of game theory, we expect tadpoles to be constrained by the spatial distribution of its food resource, whereas predaceous insects should select habitats with a high prey density, therefore we expect to find tadpoles and predaceous insects co-occurring in the same habitat patches. 


\section{Material and Methods}

\subsection{Study site}

This work was carried out in the Serra da Bocaina National Park (PNSB, hereafter) (22 $\left.44^{\prime} \mathrm{S} ; 44^{\circ} 37^{\prime} \mathrm{W}\right)$, localized at the boundary between the States of São Paulo and Rio de Janeiro in southeastern Brazil. The PNSB comprises presently an area of 104.000 ha and is regarded as one of the main remants of the Atlantic Rain Forest (sensu Ab'Saber, 1977) in southeastern Brazil, bearing protected areas of dense tropical rain forest, highland mixed tropical rain forest and highland grasslands (Eiten, 1992). Our sampling was concentrated at the area of the Bocaina highlands (1500 m a.s.l.), in the municipality of São José do Barreiro, stte of São Paulo. In this region, the climate according to the Köppen-Geiger classification (Peel et al., 2007), is of the type Cwb (humid subtropical highland), with moderated temperatures, dry winters (between April and September) and warm summers (from October to March). The annual rainfall varies between 400 and $2100 \mathrm{~mm}$, with mean annual temperature of $22^{\circ} \mathrm{C}$.

\subsection{Sampling procedures}

We sampled 13 water bodies with different morphologies and hydroperiods. The water bodies comprised: one temporary pond in woodlands (PT5), two permanent ponds in open areas (PP3 and PP4), two swamps in open areas (BP2 and BP5), four permanents ponds in woodlands (AP1, AP2, PP1, and PP2), three temporary ponds in woodlands (PT1, PT2, and PT3), and one swamp in woodlands (BP9) (veja imagens 
no Apêndice 1). Each water body was sampled once a month between June 2008 and July 2009. The tadpoles and insects were sampled using a wired deep net (3 mm of mesh) passed through the intire extent of the margins of water bodies (Shaffer et al., 1994). The tadpoles were fixed in the field with $10 \%$ formalin, while the predaceous insects were fixed in $70 \%$ alcohol. The identification followed identification keys and direct comparisons with published descriptions. When the identification was not possible using this means, we reared tadpoles in aquaria until metamorphosis, feeding them with comercial fish rations.

The taxa of predaceous insects (Cummins et al., 2008) most commonly found were Notonectidae, Ranatra travassosi (Nepidae), Lethocerus sp., Belostoma sp. (Belostomatidae), Megadytes sp., (Dytiscidae), other small bodied Dytiscidae, Gyrinus sp. (Gyrinidae), Berosus larvae (Hydrophilidae), Dytiscidae larvae, Libellulidae, Aeshnidae, Erythrodiplax sp., Tramea sp., Erythemis sp., Dasythemis sp., Dythemis sp. (Libellulidae) e Sigara sp. (Corixidae). The only fish species found in a previous sampling was Phalloceros harpagos (Teleostei: Poeciliidae), which is an insectivorous and detritivorous species (Froese and Pauly, 2009; F. Langeani, pers. comm.).

\subsection{Statistical analysis}

The co-occurrence analysis of tadpoles and predaceous insects was carried out using an incidence matrix of tadpole species and morphospecies of predaceous insects. We used a code developed by Azeria et al. (2009) which identifies by means of null models groups of species (pair-wise associations) that exhibit similar (positive associations) and distinct patterns (negative associations) of habitat use (Sanderson, 2004; Azeria et al., 2009). The significance level of pair-wise association is 
determined by the comparison of the real matrix (observed value based on C-Score index) with values of 1000 simulated matrixes; later it is calculated the number of times that the observed value is higher than the null values (Azeria et al., 2009).

This code firstly implements a calculation of the species pair-wise associations based on C-Score index (Stone and Roberts, 1990) and calculates the mean value of the index to the community with the indexes of Sørensen, Jaccard, C-Score, and StScore. Later, it compares the mean value of the index to the community and the SScore index to each pair of species against a null value (random) obtained from 1000 matrixes produced randomly (null matrixes generated by the quasiswap algorithm; Miklós and Podani, 2004). After the randomizations and comparisons of null values with observed values, the analysis generates one matrix showing the positive associations (pos), negative associations (neg), and the random associations (r) $(P>0.05)$ between the species pairs. This analysis was implemented in the programming environment R v. 2.10.0 (R Development Core Team, 2009).

\section{Results}

Contrary to our initial hypotheses, the majority of the pair-wise associations (96.33\%) between tadpoles and predaceous insects was at random. Therefore, in the spatial scale analyzed, insects did not influence habitat use by the majority of tadpoles (mean simulated C-Score $\pm \mathrm{SD}=4.02 \pm 38.6$ ). In relation to the pair-wise associations, the only positive associations (1.10\% of the total) were between NotonectidaeRhinella icterica, Notonectidae-Dendropsophus minutus, and between Gyrinus larvae-Scinax sp. (aff. obtriangulatus). On the other hand, there were negative associations (2.57\% of the total) between Chiasmocleis sp. (aff. mantiqueira)-Sigara sp., Chiasmocleis sp. (aff. mantiqueira)-Libellulidae, Chiasmocleis sp. (aff. 
mantiqueira)-Ranatra travassosi, Chiasmocleis sp. (aff. mantiqueira)-Dytiscidae larvae, Chiasmocleis sp. (aff. mantiqueira)-Notonectidae, Dendropsophus micropsDasythemis sp. and Scinax squalirostris-Dytiscidae (Table 1).

\section{Discussion}

The studied tadpole community seems not to be influenced by predaceous insects in relation to habitat use, in addition predaceous insects seem do not constrain the use of breeding sites by adults. In a study in a savanna enclave in the Amazon forest, Azevedo-Ramos et al. (1999) found that tadpoles co-occurred more frequently with predaceous invertebrates than with fishes, yet fishes were the main predators influencing species composition in tadpole communities, a result also found in other studies (Heyer et al., 1975; Kats et al. 1988; Semlitisch e Gibbons, 1988; Gascon, 1992; Hero et al., 1998; Smith et al., 1999; but see Gascon, 1989). In the present study, predaceous fish were absent, what could account for the absence of correlation at the assemblage level. On the other hand, tadpole distribution would be matching the distribution of its food resources, being the predation risk a less important factor in relation to habitat use. This argues against the majority of models, which predict that prey should take into account both the availability of resources and predation risk when selecting habitats (Dupuch et al., 2009). However, a model proposed by Luttbeg and Sih (2004) predicts that when predation risk is low (as in the case of predaceous insects, when compared to fishes, cf. Travis et al., 1985; Cronin and Travis, 1986; Semlitsch and Gibbons, 1988), prey should favor habitats richer in food resources.

Kramer et al. (1997) suggested that to animals that move between different environments in differents life stages, habitat selection occurs in a hierarquical manner, in which a general region is chosen firstly, and so successive decisions 
occurs at smaller scales, depending on microhabitat features. It is possible that patterns of habitat use in tadpoles show a similar pattern, i.e., concerning predation avoidance, the selection of microhabitats that provided a lower risk of predation should be more important (Orians and Wittenberger, 1991; Levin, 1992).

There were positive associations in habitat use between Notonectidae-Rhinella icterica, Notonectidae-Dendropsophus minutus, and between Gyrinus larvae-Scinax sp. (aff. obtriangulatus). The spatial coincidence between these taxa could suggest that similar factors that influence the diversity act in the same way to shape the tadpole and insect communities (i.e. community concordance; Warren and Gaston, 1992; Babbit et al. 2001). Data on natural history and habitat use pattern by insects are scarce, however it seems that Notonectids are easely found in shallow permanent water bodies (Streams, 1987a,b). Also, D. minutus and R. icterica were more commonly found in these kinds of water bodies (Provete et al. unpubl. ms.; Capítulo 1). Several antipredatory strategies are used by tadpoles (reviewed in Alford, 1999), including unpalatability by tadpoles of the family Bufonidae (Brodie et al. 1978), microhabitat change (Morin, 1986), and behavioral changes (Skelly, 1992; 1994; Werner and Anholt, 1993). The occurrence of these strategies is a mechanism that allows the co-occurrence of tadpoles and predaceous insects. However, more data on natural history are needed to a complete understanding of these relationships (Lima, 2002; Sanderson, 2004).

On the other hand, there were negative associations involving Chiasmocleis sp. (aff. mantiqueira) and predaceous insects from seven genera and families, and Dendropsophus microps-Dasythemis sp. and Scinax squalirostris-Dytiscidae. Chiasmocleis sp. (aff. mantiqueira) and D. microps are species associated to small ponds inside woodlands (Provete et al., unpubl. ms. - Capítulo 1). Predators seem to 
be more strongly influenced by habitat size than its prey (Roth and Jackson, 1987; Pearman, 1995; Srivastava et al., 2008). However, it seems that Corixids select large and deep ponds (Pajunen and Pajunen 2003). Furthermore, aquatic insects have limited dispersion habilities (Cummins et al., 2008), this feature could influence the colonization of ponds that are more suscetible to drought (Pearman, 1995). Another aspect that could influence the habitat use by aquatic insects, especially Odonata larvae is canopy cover (McCauley et al., 2008). In ponds occupied by $C$. aff. mantiqueira and D. microps there were a high degree of canopy cover (Provete, D.B. unpubl. ms. - Capítulo 1).

Predators generally "win" the behavioral race, i.e., occurr with their prey more than expected by chance alone (Sih, 2005). However, this seems not to be the case in the studied community. Maybe for female anurans, the main factor in selecting an oviposition site in tropical environments be the physical environment and the presence of fishes, being the risk imposed by predaceous aquatic insects less relevant. A similar outcome was observed by Resetarits and Wilbur (1989) in an experimental study, in which there was no effect in the number of eggs laid by females in treatments that included Tramea carolina larvae, the contrary of found in treatments including other vertebrate predators, such as salamander larvae (Ambystoma maculatum) and fishes (Enneacanthus chaetodon).

It is possible that habitat features are playing a major role in the habitat choice by predators and prey, and that both are being influenced by the same physical features when selecting habitat (Warren and Gaston, 1992). Our results indicate that predaceous insects do not influence habitat use by tadpoles. However, the rising of a wide variety of elaborated anti-predator strategies suggested that the coexistence of 

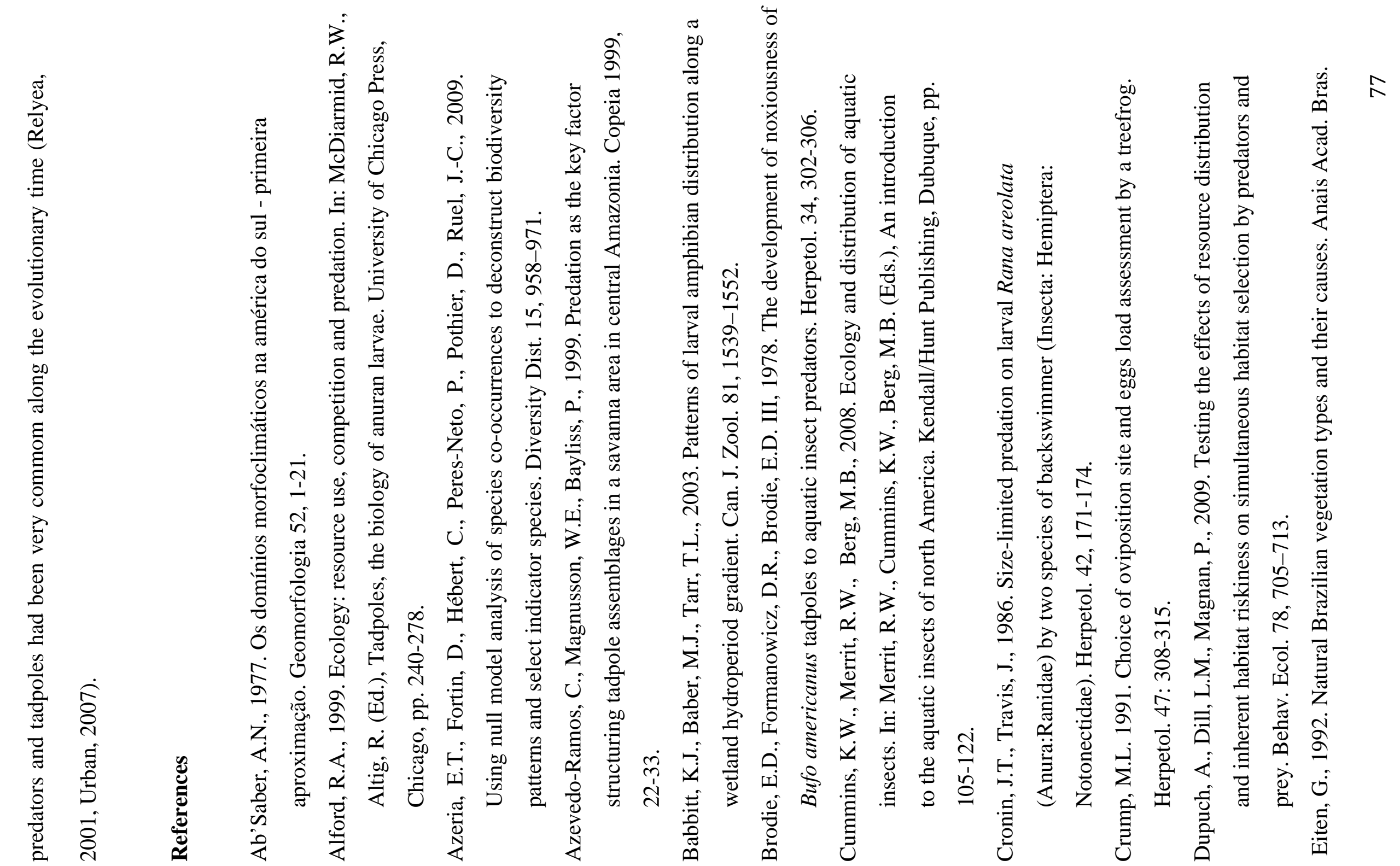

过

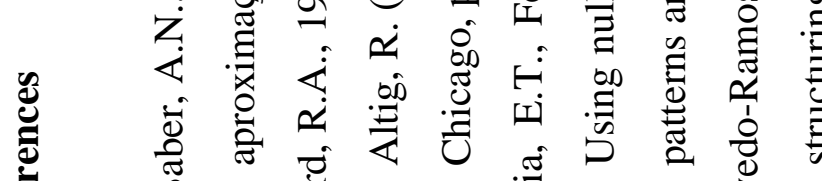

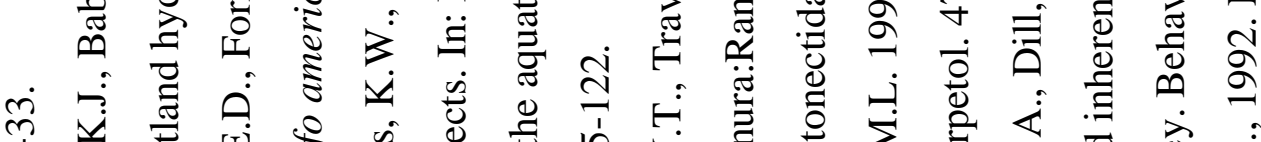
సै:

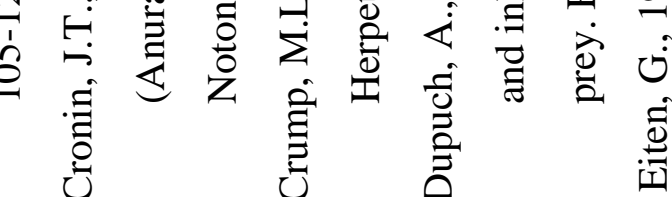


Ciênc. 64, 35-65.

Eterovick, P.C., Barata, I.M., 2006. Distribution of tadpoles within and among Brazilian streams: the influence of predators, habitat size and heterogeneity. Herpetol. 62, 365377.

Fauth, J.E., Bernardo, J., Camara, M., Resetarits, W.J., Jr., Buskirk, J.V., McCollum, S.A., 1996. Simplifying the jargon of community ecology: a conceptual approach. Am. Nat. 147, 282-286.

Fretwell, S.D., Lucas, H.L., 1970. On territorial behavior and other factors affecting habitat distribution in birds. Acta Biotheor. 19, 1-21.

Froese, R., Pauly, D. (Eds.), 2009. FishBase. World Wide Web electronic publication. Disponível em: www.fishbase.org, version (10/2009).

Gascon, C., 1989. Predator-prey interaction in tropical ponds. Rev. Bras. Zool. 6, 701-706.

Gascon, C., 1992. Aquatic predators and tadpole prey in Central Amazonia: field data and experimental manipulations. Ecology 73, 971-980.

Gotelli, N. J., Graves, G. R., 1996. Null models in ecology. Smithsonian Institution Press, Washington.

Hamilton, I.M., 2007. The ideal free distribution. In: Stephens, D.W., Brown, J.S., Ydenberg, R.C. (Eds.), Foraging, behavior and ecology. University of Chicago Press, Chicago, pp. 333-335.

Hammond, J.I., Luttberg, B., Sih, A., 2007. Predator and prey space use: dragonflies and tadpoles on an interactive game. Ecology 88, 1525-1535.

Harvey, P.H., Colwell, R.K., Silvertown, J.W., May, R.M., 1983. Null models in ecology. Ann. Rev. Ecol. Syst. 14, 189-211.

Hero, J.-M., Gascon, C., Magnusson, W.E., 1998. Direct and indirect effects of predation on tadpole community structure in the Amazon rainforest. Austral Ecology 23, 474-482.

Heyer, W.R., McDiarmid, R.W., Weigmann, D.L., 1975. Tadpoles, predation and pond habitat in the tropics. Biotropica 7, 100-111.

Hopey, M.E., Petranka, J.W., 1994. Restriction of Wood Frogs to fish-free habitats: how important is adult choice? Copeia 1994, 1023-1025.

Hugie, D.M., Dill, L.M., 1994. Fish and game: a game theoretic approach to the habitat selection by predators and prey. J. Fish Biol. 45, 151-169.

Kats, L.B., Petranka, J.W., Sih, A., 1988. Antipredator defenses and the persistence of amphibian larvae with fishes. Ecology 69, 1865-1870. 
Kramer, D.L., Rangeley, R.W., Chapman, L.J., 1997. Habitat selection: patterns of distribution from behavioral decisions. In: Godin, J.-G. (Ed.), Behavioral ecology of teleost fishes. Oxford University Press, Oxford, pp. 37-80.

Levin, S. A., 1992. The problem of pattern and scale in ecology: The Robert H. MacArthur Award Lecture. Ecology 73, 1943-1967.

Lima, S.L., 2002. Putting predators back into behavioral predator-prey interactions. Trends Ecol. Evol.17, 70-75.

Lima, S.L., Dill, L.M., 1990. Behavioral decisions made under the risk of predation: a review and prospectus. Can. J. Zool. 68, 619-640.

Luttbeg, B., Sih, A., 2004. Predators and prey habitat selection games: the effects of how prey balance foraging and predation risk. Israel J. Zool. 50, 233-254.

Maynard Smith, J., 1982. Evolution and the theory of games. Cambridge University Press, Cambridge.

McCauley, S.J., Davis, C.J., Relyea, R.A., Yurewicz, K.L., Skelly, D.K., Werner, E.E., 2008. Metacommunity patterns in larval odonates. Oecologia 158, 329-342.

Miklós, I., Podani, J., 2004. Randomization of presence-absence matrices: comments and new algorithms. Ecology 85, 86-92.

Morin, P.J., 1983. Predation, competition, and the composition of larval anuran guilds. Ecology 53, 119-138.

Morin, P.J., 1986. Interactions between intraspecific competition and predation in an amphibian predator-prey system Ecology 67, 713-720.

Orians, G.H., Wittenberger, J.F., 1991. Spatial and temporal scales in habitat selection. Am. Nat. 137, S29-S49.

Paine, R.T., 1966. Food web complexity and species diversity. Am. Nat. 100, 65-75.

Pajunen, V.I., Pajunen, I., 2003. Habitat selection in rock pool corixids: the effect of local density on dispersal. Hydrobiol. 495, 73-78.

Pearman, P.B., 1995. Effects of pond size and consequent predator density on two species of tadpoles. Oecologia 102, 1-8.

Peel, M.C., Finlayson, B.L., McMahon, T.A., 2007. Updated world map of the Köppen-Geiger climate classification. Hydrol. Earth Syst. Sci. 11, 1633-1644.

Peres-Neto, P.R., Olden, J.D., Jackson, D.A., 2001. Environmentally constrained null models: site suitability as occupancy criterion. Oikos 93, 110-120. 
R Development Core Team, 2009. R: a language and environment for statistical computing. R Foundation for Statistical Computing, Vienna, Austria. Available at: http://www.R-project.org

Relyea, R.A., 2001. Morphological and behavioral plasticity of larval anurans in response to different predators. Ecology 82, 523-540.

Roth, A.H., Jackson, J.F., 1987. The effect of pool size on recruitment of predatory insects and on mortality in a larval anuran. Herpetol. 43, 224-232.

Sanderson, J.G., 2004. Null model analysis of communities on gradients. J. Biogeogr. $31,879-883$.

Semlitsch, R.D., Gibbons, J.W., 1988. Fish predation in size-structured populations of treefrog tadpoles. Oecologia 75, 321-326.

Shaffer, H.B., Alford, R.A., Woodward, B.D., Richards, S.J., Altig, R. and Gascon, C., 1994. Quantitative sampling of amphibian larvae. In: Heyer, W.R., Donnelly, M.A., McDiarmid, R.W., Hayek, L.-A.C. and Foster, M. (Eds.), Measuring and monitoring biological diversity - Standard methods for amphibians. Smithsonian institution press, Washington, pp. 130-140.

Sih, A., 1984. The behavioral response race between predator and prey. Am. Nat. 123, 143-150.

Sih, A., 1987. Predators and prey lifestyles: an evolutionary and ecological overview. In: Kerfoot, W.C. e Sih, A. (Eds.), Predation, direct and indirect impact on aquatic communities. University Press of New England, Hanover, pp. 203-224.

Sih, A. 2005. Predator-prey space use as an emergent outcome of a behavioral response race. In: Barbosa, P., Castellanos, I. (Ed.), The ecology of predatorprey interactions. Oxford University Press, Oxford, pp. 240-255.

Sih, A., Crowley, P., McPeek, M.A., Petranka, J., Strohmeier, K., 1985. Predation, competition, and prey communities: a review of field experiments. Ann. Rev. Ecol. Syst. 16, 269-311.

Skelly, D.K., 1992. Field evidence for a cost of behavioral antipredator response in a larval amphibian. Ecology 73, 704-708.

Skelly, D.K., 1994. Activity level and the susceptibility of anuran larvae to predation. Anim. Behav. 47, 465-468.

Skelly, D.K., 1995. A behavioral trade-off and its consequences for the distribution of Pseudacris treefrog tadpoles. Ecology 76, 150-164.

Smith, G.R., Rettig, J.E., Mittelbach, G.G., Valiulis, J.L., Schaack, S.R., 1999. The effects of 
fish on assemblages of amphibians in ponds: a field experiment. Freshwater biology 41, 829-837.

Srivastava, D.S., Trzcinski, M.K., Richardson, B.A., Gilbert, B., 2008. Why are predators more sensitive to habitat size than their prey? Insights from bromeliad insect food webs. Am. Nat. 172, 761-771.

Stone, L., Roberts, A., 1990. The checkerboard score and species distribution. Oecologia 85, 74-79.

Streams, F. A., 1987a. Within-habitat spatial separation of two Notonecta species: interactive vs. noninteractive resource partitioning. Ecology 68, 935-945.

Streams, F. A., 1987b. Foraging behavior in a Notonectid assemblage. Am. Mid. Nat. $117,353-361$.

Travis, J., Keen, W.H., Juilianna, J., 1985. The role of relative body size in a predator-prey relationship between dragonfly naiads and larval anurans. Oikos $45,59-65$.

Urban, M.C., 2007. Risky prey behavior evolves in risky habitats. Proc. Nat. Acad. Sci. USA 104, 14377-14382.

Warren, P.H., Gaston, K.J., 1992. Predator-prey ratios: a special case of a general pattern? Phil. Trans. Royal Soc. London B 338, 113-130.

Werner, E.E., 1998. Ecological experiments and a research program in community ecology. In: Resetaritis, W.J. e Bernardo, J. (Eds.), Experimental Ecology: Issues and Perspectives. Oxford University Press, Oxford, pp. 3-26.

Werner, E.E., Gilliam, J.F., 1984. The ontogenetic niche and species interactions in size-structured populations Ann. Rev. Ecol. Syst. 15, 393-425.

Werner, E.E., Anholt, B.R., 1993. Ecological consequences of the trade-off between growth and mortality rates mediated by foraging activity. Am. Nat. 142, 242272.

Wilbur, H.M., 1988. Interactions between growing predators and growing prey. In: Ebenman, B. (Ed.), Size-structured populations: ecology and evolution. Springer-Verlag, Berlin, pp. 157-172. 


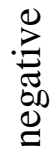

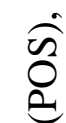

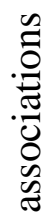

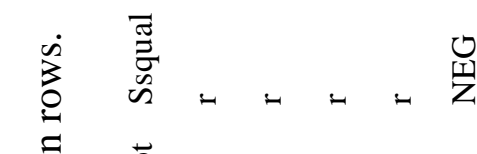

D

$\stackrel{\Xi}{\circ}$

过

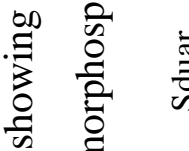

ن

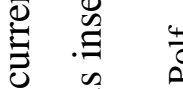

$\begin{array}{lll}0 & 0 \\ 0 & 0 & 0 \\ 0 & 0 & 0 \\ 0 & 0 & 0\end{array}$

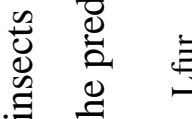

苛 芩

总寻

究

吉 $+\cdots+\cdots+\cdots$

ส .

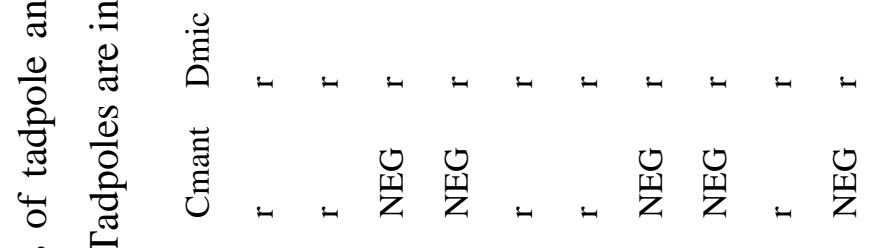

离

ฮ

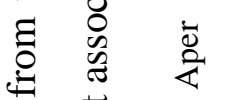

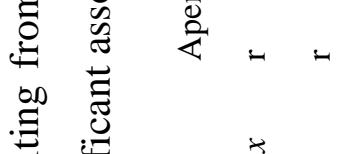

恶

离

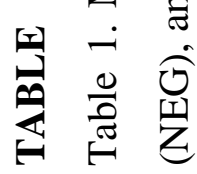

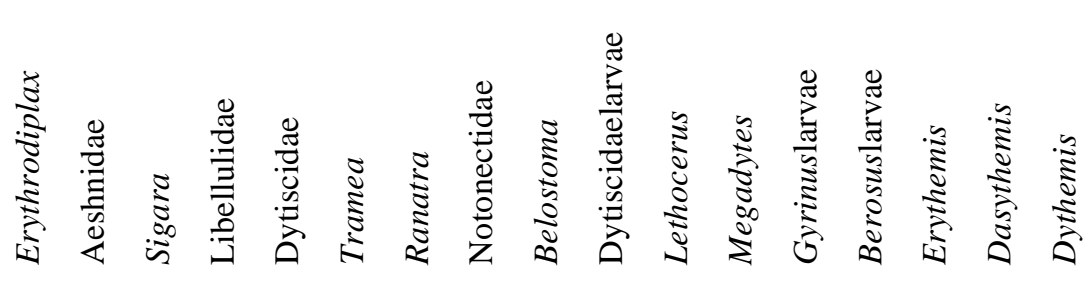




\section{CDNSIDERAÇŨES FINAIS}

- As interações interespecíficas desempenharam um papel secundário na estruturação da comunidade de girinos estudada em favor da regulação ambiental. Esta constatação está em acordo com a visão Gleasoniana individualísta de comunidade, ou seja, de que a organização de comunidades depende largamente de fenômenos que ocorrem na escala do indivíduo e de como estes respondem aos fatores ambientais.

- Os resultados apresentados no capítulo 1 sugerem que as larvas de espécies de anuros apresentam uma resposta espécie-específica a diversos fatores abióticos, notavelmente na maneira como estas respondem aos gradientes de hidroperíodo e de cobertura de dossel. Demonstramos que esses dois gradientes ambientais influenciaram a distribuição de espécies nos corpos d'água amostrados, além de afetar a diversidade de espécies, já que as poças permanentes foram as mais diversas.

- Os resultados apresentados no capítulo 2 sugerem que o alimento parece ser o eixo do nicho em que há maior sobreposição, embora este resultado esteja em acordo com outros registros feitos da literatura, acreditamos que o uso de diferentes microhábitas pelas larvas de espécies de anuros pode ser um fator que poderia contribuir para a partilha de recursos alimentares.

- Os resultados apresentados no capítulo 3 demonstraram que a seleção de hábitat pelas larvas de espécies de anuros não foi influenciada pela presença de insetos predadores. Ao invés disso, sugerimos que novamente fatores abióticos, tais como os gradientes de hidroperíodo e cobertura de dossel, poderíam influenciar a distribuição das larvas de espécies de anuros nos corpos d'água amostrados e que ambos girinos e insetos estejam selecionando corpos d'água em relação a esses fatores ambientais e que o risco de predação desempenhe um papel secundário nesse processo.

- O fenômeno de "species sorting" e teorias baseadas no nicho podem ser evocadas para explicar a maioria dos padrões encontrados. 


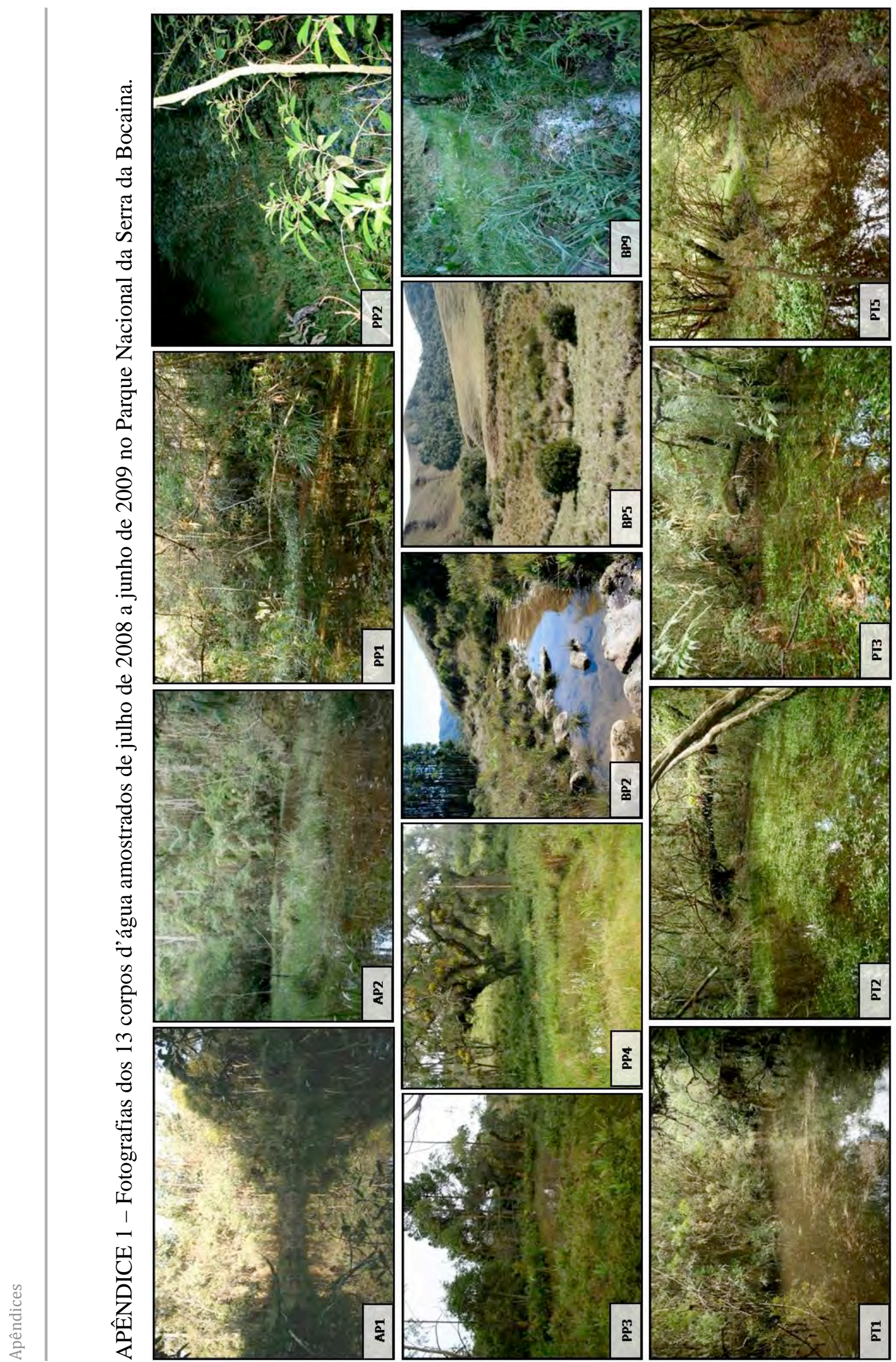


APÊNDICE 2 - Lista das espécies de anfíbios registradas na fase larval, de julho de 2008 a junho de 2009 no Parque Nacional da Serra da Bocaina.

Amphibia (Gray, 1825)

Anura (Fischer von Waldheim, 1813)

Bufonidae (Gray, 1825)

Rhinella icterica (Spix, 1824)

Cycloramphidae (Bonaparte, 1850)

Cycloramphinae (Bonaparte, 1850)

Proceratophrys melanopogon (Miranda-Ribeiro, 1926)

Hylidae (Rafinesque, 1815)

Hylinae (Rafinesque, 1815)

Cophomantini Hoffmann, 1878

Aplastodiscus perviridis (Lutz in Lutz, 1950)

Bokermannohyla ahenea (Napoli \& Caramaschi, 2004)

Bokermannohyla sp. (gr. circumdata)

Hypsiboas sp. (aff. polytaenius)

Dendropsophryni Fitzinger, 1843

Dendropsophus microps (Peters, 1872)

Dendropsophus minutus (Peters, 1872)

Scinax sp. (aff. alter)

Scinax sp. (aff. duartei)

Scinax sp. (aff. hayii)

Scinax sp. (aff. obtriangulatus)

Scinax squalirostris (Lutz, 1925)

Leiuperidae

Physalaemus barrioi Bokermann, 1967

Physalaemus olfersii (Lichtenstein \& Martens, 1856)

Leptodactylidae

Leptodactylus furnarius Sazima \& Bokermann, 1978

Microhylidae

Gastophryninae Fitzinger, 1843

Chiasmocleis sp. (aff. mantiqueira) 
APÊNDICE 3 - Lista de espécies de insetos aquáticos encontrados nos corpos d'água amostrados no Parque Nacional da Serra da Bocaina, de julho de 2008 a junho de 2009.

Insecta

Coleoptera

Dryopidae

Dryops sp.

Dytiscidae

Copelatus sp.

Cybister sp.

Hydrocantus sp.

Megadytes sp.

Gyrinidae

Gyrinus sp.

Hydrophilidae

Berosus sp.

Tropisternus sp.

Hemiptera

Heteroptera

Nepomorpha

Belostomatidae

Belostoma sp.

Belostoma discretum

Lethocerus sp.

Lethocerus meloleitaoi

Corixidae

Sigara sp.

Naucoridae

Ctenipocoris sp.

Limnocoris brasiliensis

Limnocoris nigropunctatus

Nepidae

Ranatra segrega 
Ranatra travassosi

Notonectidae

Buenoa sp. nov.

Buenoa sp. (aff. macrotrichia)

Notonecta sp.

Notonecta polystolisma

Megaloptera

Corydalidae

Corydallus sp.

Odonata

Anisoptera

Aeshnidae

Aeshna sp.

Anax sp.

Castoraeschna sp.

Gynacantha sp.

Rhionaeschna sp.

Cordulidae

Cordulisantosia sp.

Neocordulia sp.

Libellulidae

Dasythemis sp.

Dythemis sp.

Erythemis sp.

Erythrodiplax sp.

Orthemis sp.

Tramea sp.

Zygoptera

Calopterygidae

Haeterina sp.

Caenoagrionidae

Acanthagrion sp.

Oxyagrion sp.

Lestidae 
Lestes sp.

Perilestes sp.

Plecoptera

Perlidae

Kempnyia sp.

Trichoptera

Barypenthus sp.

Grumichella sp.

Macronema sp.

Nectopsyche sp.

Oecetis sp. 